GEOGRAFICKÝ ČASOPIS / GEOGRAPHICAL JOURNAL 72 (2020) 4, 391-416

DOI: https://doi.org/10.31577/geogrcas.2020.72.4.20

\title{
GEOGRAFICKÝ ČASOPIS: SEDEMDESIAT ROKOV FORMOVANIA GEOGRAFICKÉHO MYSLENIA NA SLOVENSKU
}

\author{
Vladimír Ira*, Eva Ďurišová*, Pavel Šuška* \\ * Geografický ústav Slovenskej akadémie vied, Štefánikova 49, 81473 Bratislava, Slovensko \\ geogira@savba.sk,geokniz@savba.sk,geogsusk@savba.sk
}

\begin{abstract}
Geografický časopis / Geographical Journal: 70 years shaping geographical thought in Slovakia

Seventy years since the publication of the first issue of Geografický časopis/ Geographical Journal (entitled Geographica Slovaca in 1949) inspired the authors of the paper to think not only about the transformations of this oldest Slovak geographical journal, but also to pay attention to its significance /importance and heritage. The paper briefly but comprehensively analyses the period of seventy years of publishing this periodical and presents the conceptual, theoretical and methodological changes in geographical thoughts as reflected in the contributions to the Journal. An important part of the paper is the analysis of the content, categorization of papers and the development of geographical topics in three periods: $1949-1968,1969-1989$ and 1990 - 2018. Attention is paid to the authorial and institutional aspect of the contributions, the editorial board and changes in the periodical in terms of formal structure. The last part of the paper focuses on a citation analysis of the Journal based on the WOS and SCOPUS databases, as well as a comparison of the Geografický časopis with other significant scientific journals in the field published in Central Eastern Europe.
\end{abstract}

Key words: Geografický časopis / Geographical Journal, development analysis, scientometric analysis, development of geographical thought, Central Eastern Europe

\section{ÚVOD}

Začiatkom roku 1665 boli publikované prvé vedecké časopisy. Vo Francúzsku to bol časopis Journal des sçavans a v Anglicku Philosophical Transactions of the Royal Society. Počas viac ako 350 rokov zastávali vedecké periodiká mnoho úloh. Okrem ukladania záznamov z výsledkov výskumu umožnili v (časo)priestore rozptýleným vedcom komunikovat' o ich výskume. Pomohli založit' vedomostné spoločenstvá a umožnili budovat' a udržiavat' vzt'ahy nielen medzi učenými spoločnost'ami, ale aj medzi jednotlivými bádatel'mi. Vždy boli súčast'ou vzájomne prepojenej siete, prostredníctvom ktorej sa šírili vedomosti (Fyfe et al. 2015).

Geografia ako vedná disciplína má dlhú históriu, ale jej formálna inštitucionalizácia na akademickú disciplínu s vlastnou samostatnou identitou je fenoménom konca devätnásteho a začiatku dvadsiateho storočia. „Úplná inštitucionalizácia“ sa podl'a Johnstona (2003) uskutočnila až v 20. storočí. Založenie katedier a ústavov geografie na univerzitách, zavedenie študijných programov geografie, zakladanie vedeckých spoločností a vykonávanie geografického výskumu bolo súčast'ou širšieho spektra procesov. Jeho zložkou bolo aj zriad'ovanie stredísk na publikovanie výsledkov výskumu v geografii. Vedecké spoločnosti a univerzitné a vedeckovýskumné pracoviská postupne začali v 19. storočí vydávat' geografické periodiká - napr. The Geographical Journal (1831) v Spojenom král'ovstve, Bulletin of the American Geographical Society (1852) v USA, Mitteilungen der Österreichischen Geographischen Gesellschaft (1856) v Rakúskom cisárstve, Bulletin et Mémoires de la Société de géographie de Genève (1860) vo Švajčiarskej konfederácii, 
Известия императорского русского географического общества (1865) v Rusku, Boletín de la Real Sociedad Geográfica (1876) v Śpanielskom král'ovstve, Scottish Geographical Magazine (1885) v Spojenom král'ovstve, Fennia (1889) vo Fínskom vel'kovojvodstve, Annales de géographie (1891) vo Francúzsku, Geographische Zeitschrift (1895) v Nemeckom cisárstve a Geographica Helvetica (1899) vo Švajčiarskej konfederácii. Medzi periodiká z 19. storočia môžeme zaradit' aj časopis v českom jazyku s názvom Sborník České společnosti zeměvědné, ktorý začal vychádzat's vročením 1895 (Jeleček a Martínek 2007).

Za prvé slovenské vedecké periodikum sa považuje až Letopis Matice Slovenskej (založený 1864), ktorý uverejňoval články z histórie, filozofie aj prírodných vied. Prvý slovenský vedecký časopis, ktorý vychádza dodnes, je Právny obzor vydávaný od roku 1917 (Dobbersteinová et al. 2019). Podmienky pre systematický rozvoj publikovania výsledkov vedy v slovenskom jazyku vznikli až po prvej svetovej vojne po založení Československej republiky (1918).

Pred rokom 1949 neexistoval na Slovensku žiadny vyhradený časopis pre výskum v oblasti geografie a publikovanie výsledkov výskumu bolo rozptýlené v širokej škále vedeckých časopisov, resp. v geografických časopisoch v zahraničí alebo v českých krajinách. K vyplneniu tejto medzery významne prispel novozaložený geografický časopis Geographica Slovaca, ktorý neskôr dostal názov Geografic$k y ́$ časopis.

Hodnoteniu významu jednotlivých časopisov, ako aj tradičným prehl'adovým analýzam sa venuje v odbornej literatúre celý rad príspevkov, ktoré boli publikované ako analýzy pri výročiach založenia časopisov (napr. de Pater 2009, Price 2010, Griffith et al. 2013, Sleszyński 2014, Ira 2017, Bissell 2019, Knowles 2019, Witlox a Schwanen 2019 a Ward et al. 2020), resp. pri hodnotení výskumnej činnosti a publikačných výstupov relevantných inštitúcií (napr. Mazúr 1978, Bezák 1993, Kvitkovič 1993, Zudel 1993, Matlovič 2011, Hofierka a Gallay 2013, Ira 2013, Jančák a Siwek 2014 a Pacione 2014). Významnou oblast'ou prehl'adov a komparácií sú články venované citačným ohlasom (napr. Blažek 1986, Bosman 2009, Bajerski a Siwek 2012, Jančák a Siwek 2014, Pacione 2014 a Ira et al. 2016).

Sedemdesiat rokov od vydania prvého čísla nášho periodika v roku $1949 \mathrm{~s}$ názvom Geographica Slovaca nás inšpirovalo k tomu, aby sme sa zamysleli nielen nad premenami tohoto najstaršieho slovenského geografického časopisu, ale venovali pozornost' aj jeho významu a odkazu. V článku sa pokúšame stručne a komplexne analyzovat' obdobie sedemdesiatich rokov vydávania tohto periodika a predstavit' konceptuálne, teoretické a metodologické zmeny v geografickom myslení tak, ako ho reflektovali príspevky v Geografickom časopise. Príspevok teda sleduje ciel' predstavit' sedem desat'ročí vo vývoji časopisu a na základe stručnej analýzy publikovaných štúdií a článkov poukázat' na niektoré črty vývoja geografického myslenia na Slovensku. Na základe scientometrických porovnaní sa pokúša aj charakterizovat' postavenie Geografického časopisu v medzinárodnom kontexte geografických periodík stredo-východoeurópskeho priestoru.

V nasledujúcich častiach článku sa usilujeme o rozbor periodika z rôznych hl'adísk. Dôležitú súčast' príspevku tvorí analýza obsahovej stránky, kategorizácia príspevkov a vývoj geografie v nami definovaných troch časových obdobiach. Pozornost' je venovaná autorskému a inštitucionálnemu hl'adisku príspevkov, redakčnej rade a zmenám periodika z hl'adiska formálnej štruktúry. V poslednej časti článok prináša citačnú analýzu časopisu na základe databáz WOS a Scopus, ako aj kompa- 
ráciu Geografického časopisu s inými vedeckými časopismi v odbore, vydávanými v stredo-východoeurópskom priestore (zvolená metodika na základe citačných indexov databázy Scopus).

\section{VZNIK, VÝVOJ, ZÁKLADNÁ CHARAKTERISTIKA A FORMÁLNA STRÁNKA ČASOPISU}

Geografický časopis (printová verzia: ISSN 0016-7193, online: ISSN 24538787) je recenzovaný vedecký časopis, ktorý uverejňuje pôvodné vedecké štúdie prinášajúce najnovšie poznatky zo všetkých oblastí geografie a významné príspevky z príbuzných vedných disciplín (krajinná ekológia, hydrológia, klimatológia, pedológia environmentalistika, kartografia, geoinformačná veda, demografia, sociológia a ekonómia). Pri výbere príspevkov sa uprednostňujú najmä štúdie venované geografickému výskumu Slovenska a krajín stredoeurópskeho priestoru, ako i teoreticko-metodologickým otázkam geografického bádania. V súčasnosti časopis vychádza štyrikrát ročne v slovenskom alebo českom jazyku s anglickým resumé, prípadne v anglickom jazyku so slovenským resumé. Časopis je prístupný na webovej stránke http://geograficky-casopis.sav.sk/.

V súčasnosti Geografický časopis publikuje vedecké príspevky ôsmej dekády svojej existencie. Zrod a genéza periodika je spojená s históriou jeho vydavatel'a, a to bývalého Zemepisného ústavu Slovenskej akadémie vied a umení (založeného v roku 1943), ktorý sa v roku 1953 transformoval do Zemepisného ústavu SAV a neskôr v roku 1963 do dnešného Geografického ústavu SAV. V nasledujúcich riadkoch je zdokumentovaná formálna štruktúra periodika a jej vývojové zmeny.

Časopis vznikol v roku 1949 pod názvom Geographica Slovaca ako zborník príspevkov venovaných zakladatelovi modernej slovenskej geografie profesorovi Jánovi Hromádkovi. Prvým článkom prvého čísla časopisu bol príspevok zodpovedného redaktora M. Lukniša (1949) hodnotiaci život a dielo prof. Hromádku. Príspevky obsahovali resumé vo francúzštine a abstrakt v angličtine.

Ďalšie tri roky (1950 - 1952) vychádzal pod názvom Zemepisný sborník SAVU. V roku 1950 a 1952 vyšli dve dvojčísla a v roku 1951 vyšlo iba jedno číslo periodika $\mathrm{v}$ béžovej obálke. Z hl'adiska typológie príspevky tvorili štúdie, správy, recenzie, niektoré čísla uvádzali i obsahy zahraničných geografických časopisov. Články a štúdie obsahovali resumé v ruštine, francúzštine, prípadne v nemčine. Citovaná literatúra bola vykazovaná za textom príspevkov alebo pod čiarou na jednotlivých stranách. V roku 1953 sa novým štatútom mení Zemepisný ústav SAVU na Zemepisný ústav SAV a od tohto roku periodikum dostáva názov Geografický časopis (1953 až do súčasnosti).

Obdobie, počas ktorého vychádza časopis, bolo sprevádzané viacerými obsahovými i formálnymi zmenami. Od roku 1953 sa obsah časopisu členil na štúdie, správy, recenzie (alebo literatúra). V roku 1966 pribudla nová kategória - vedecké správy. Takáto obsahová špecifikácia zostala zachovaná do roku 1991. V ojedinelých prípadoch boli publikované príspevky z vedeckých podujatí. Zmena základnej štruktúry nastáva $\mathrm{v}$ roku 1992, ked' obsah už nevymedzuje kategóriu príspevku (štúdie a správy). V jednotlivých číslach sa ešte vyskytujú recenzie kníh (literatúra) až do roku 2006. Od tohto roku sú v obsahu zaznamenané len vedecké články autorov. Periodicita vydávania bola počas celého obdobia štvrt'ročná (štyri čísla), zriedkavo sa vyskytli aj dvojčísla. 
Niekol'kokrát sa menila vonkajšia stránka časopisu: modrá obálka (1953 _ 1955), obálka žltej farby (1956 - 1967) a oranžová od roku 1968. V roku 1992 nastala zmena, ked' matnú obálku vystriedala lesklá. Súčasná obálka, navrhutá vtedajšou vedeckou pracovníčkou ústavu M. Cebecauerovou, sa datuje od roku 2009 (bielo-oranžovo-fialová farba). Zmeny sa d'alej týkali vel'kosti a typu písma, jazykových mutácií v súhrnoch (resumé) i abstraktoch, tiráže a základných údajov o časopise, uvádzania recenzentov (roky 1959 - 1967) a afiliácie autorov. Zoznam literatúry (citácie) bol číslovaný poradovým číslom až do roku 1992. V súčasnosti je literatúra $\mathrm{v}$ zozname uvádzaná $\mathrm{v}$ abecednom poradí.

Geografický časopis (d’alej skratka GČ) je indexovaný v citačnej databáze Scopus, a to za roky 1979 - 1995 a od roku 2007 do súčasnosti. Výber záznamov z GČ sme našli aj v bibliografických databázach Georef, ECONIS, Geobibline a EBSCO. V roku 2018 bola podaná žiadost' o zaradenie časopisu do svetovej citačnej databázy Web of Science a v súčasnosti je vo fáze hodnotiaceho procesu.

V rokoch 1949 - 2018 bolo vydaných 253 čísiel a v časopise bolo uverejnených 1366 článkov, štúdií a vedeckých správ, ktoré pripravilo spolu 1868 autorov. Väčšina (1 110 článkov) bola publikovaná v slovenčine a češtine, 227 v anglickom jazyku, 24 v nemčine, 4 v ruštine a 1 vo francúzštine.

Rozsah všetkých článkov do roku 2018 predstavuje 20585 strán, priemerný rozsah publikovaného príspevku tvoril spolu 15 strán textu, súhrnu a citovanej literatúry. Vyskytli sa prípady diskusie medzi autormi, ktoré mali len dížku dvoch strán. Najdlhší článok bol publikovaný na 54 stranách (text článku, literatúra a abstrakt). V súčasnosti rozsah (20 normalizovaných strán) a formu zasielaných príspevkov vymedzujú pokyny pre autorov, ktoré sú uvedené na webovej stránke a na tretej strane obálky časopisu. Priemerne pripadá na článok 17 referencií, tu však je potrebné podotknút, že niektoré staršie príspevky nemali uvedenú použitú literatúru. Najviac, 218 referencií obsahoval hodnotiaci príspevok J. Hanzlíka (1967): Vývoj obyvatel'stva na Slovensku v období 1869 - 1961.

Za širokým a pestrým spektrom problémov publikovaných na stránkach GČ sa skrýva dôležitý celostný alebo syntetický aspekt. Množina týchto problémov gravituje k centrálnemu problému, ktorým je časovo-priestorová koexistencia (interakcia) prírody a spoločnosti. Táto celostná interdisciplinárna orientácia bola zrejmá už v prvom čísle časopisu, ktoré nadväzovalo na odkaz prof. J. Hromádku.

\section{AUTORSKÁ A INŠTITUCIONÁLNA ANALÝZA PRÍSPEVKOV}

Najvýraznejšia skupina prispievatel'ov v GČ boli slovenskí a českí autori z vedecko-výskumných inštitúcií a vysokých škôl. Najpočetnejšie boli zastúpení autori z vydavatel'skej inštitúcie, Geografického ústavu SAV, ktorí v časopise prezentovali výsledky svojich výskumov z vedeckých projektov. V ostatnom desat'ročí sa účast' domácich autorov zúžila na jeden až dva články v čísle časopisu, v súčasnosti prevládajú príspevky autorov z iných slovenských inštitúcií a zo zahraničia. Do konca roku 2018 bolo 1103 článkov publikovaných s aspoň jedným autorom zo Slovenska (v tom sú zahrnuté aj bývalé formy štátneho usporiadania pred rokom 1993). Prehl'ad autorov s najvyšším počtom publikácií za obdobie 1949 - 2018 uvádza tab. 1. 
Tab. 1. Najčastejšie publikujúci autori v Geografickom časopise

\begin{tabular}{|c|c|c|c|}
\hline Poradové číslo & Meno autora & Počet článkov & Pracovisko (afiliácia autora) \\
\hline 1. & Urbánek, J. & 42 & GgU SAV \\
\hline 2. & Mazúr, E. & 39 & GgÚ SAV \\
\hline 3. & Pravda, J. & 32 & GgÚ SAV \\
\hline 4. & Plesník, P. & 27 & PriF UK \\
\hline 5. -6 . & Feranec, J. & 24 & GgÚ SAV \\
\hline 5. -6 . & Ot'ahel', J. & 24 & GgÚ SAV \\
\hline 7. -8 . & Lukniš, M. & 23 & PriF UK \\
\hline 7. -8 . & Mariot, $\mathrm{P}$. & 23 & GgÚ SAV \\
\hline $9 .-11$. & Krcho, J. & 22 & PriF UK \\
\hline 9. -11 . & Kvitkovič, J. & 22 & GgÚ SAV \\
\hline 9. -11 . & Solín, L'. & 22 & GgÚ SAV \\
\hline 12. -15 . & Drdoš, J. & 19 & GgÚ SAV \\
\hline 12. -15 . & Hanušin, J. & 19 & GgÚ SAV \\
\hline $12 .-15$ & Jakál, J. & 19 & GgÚ SAV \\
\hline 12. -15 . & Porubský, A. & 19 & GgÚ SAV \\
\hline 16. -18 . & Grešková, A. & 18 & GgÚ SAV \\
\hline 16. -18 . & Lehotský, M. & 18 & GgÚ SAV \\
\hline 16. -18 . & Očovský, Š. & 18 & GgÚ SAV \\
\hline 19. -20 . & Bedrna, Z. & 17 & ÚKE SAV+PriF UK \\
\hline 19. -20 . & Michálek, A. & 17 & GgÚ SAV \\
\hline
\end{tabular}

Zdroj: GgÚ SAV - Geografický ústav Slovenskej akadémie vied, PriF UK Bratislava - Prírodovedecká fakulta Univerzity Komenského v Bratislave a ÚKE SAV - Ústav krajinnej ekológie Slovenskej akadémie vied.

Zo zahraničných prispievatel'ov publikovali v GČ autori z Pol'ska (34 článkov), Nemecka (14), Mad'arska (13), bývalého Sovietskeho zväzu a Ruska (13), Rumunska (6), Rakúska (5), Anglicka (4), Francúzska (3) a iných krajín (Bulharsko, Fínsko, Egypt, Grécko, Holandsko, Taliansko, India, Irak, Írsko, Japonsko, Kanada, Mexiko, Slovinsko, Sudán a Švajčiarsko). Ćísla nie sú presné, sú neúplné, ked’že afiliácie neboli uvádzané vo všetkých číslach časopisu. Pracoviská autorov neboli zaznamenávané v rokoch 1949, 1950, 1952, 1953, 1965, 1968 - 1983, čiastočne sú uvádzané v rokoch 1951, 1954 - 1958, 1960 - 1964 a 1966 - 1967.

Okrem autorov z Geografického ústavu SAV sa na publikovaní v GČ výraznejšie podiel'ali autori z nasledovných inštitúcií na Slovensku (najmä vysokých škôl a výskumných ústavov): Univerzita Komenského v Bratislave (najmä Prírodovedecká fakulta), Prešovská univerzita v Prešove, Univerzita Mateja Bela v Banskej Bystrici, Univerzita Pavla Jozefa Šafárika v Košiciach, Katolícka univerzita v Ružomberku, Výskumný ústav pôdoznalectva a ochrany pôdy (Bratislava a Prešov), Hydrometeorologický ústav (Bratislava a Košice), Ústav krajinnej ekológie SAV a Geologický ústav SAV. Z českých a moravských pracovísk to boli predovšetkým: Geografický ústav ČSAV Brno, Ústav geoniky AV ČR Brno, Palackého univerzita v Olomouci, Ostravská univerzita, Ostrava, Masarykova univerzita (do roku 1990 Univerzita J. E. Purkyně) v Brne a Univerzita Karlova v Prahe.

Medzi významnými zahraničnými autormi možno spomenút' celý rad renomovaných prispievatel’ov z Česka (vrátane bývalého Československa) - J. Blažek, M. Blažek, R. Brázdil, T. Czudek, J. Demek, V. Gardavský, M. Hampl, V. Häufler, A. Hynek, P. Chalupa, J. Kalvoda, V. Král, J. Korčák, J. Krejčí, K. Kuchař, A. Panoš, J. Pelíšek, V. Srb, L. Sýkora, T. Siwek, A. Vaishar a F. Vitásek. Výrazné zastúpenie mali aj významní pol’skí autori, napr. J. Bański, S. Berezowski, P. Eberhardt, T. 
Gerlach. M. Klimaszewski, T. Komornicki, M. Rościszewski, L. Starkel, L. Straszewicz, T. Stryjakiewicz, Z. Taylor, M. Więckowski a T. Zietara. Z dôležitých nemeckých autorov možno spomenút' mená: K. Billwitz, G. Haase, H. Hagedorn, H. Karrasch, H. Richter a W. Sperling. Medzi významnými autormi boli aj mad'arskí geografi: I. Berényi, Z. Dővényi. S. Katona, E. Kiss, K. Kocsis a M. Pécsi, ako aj predstavitelia sovietskej, resp. ruskej, geografie: D. L. Armand, I. P. Gerasimov, S. P. Chromov, I. P. Isačenko a D. Lilienberg. Z USA treba spomenút' autorov S. D. Brunna, B. E. Montz a geografa slovenského pôvodu P. Sisku. Medzi uznávanými autormi z Rakúska mohli čitatelia GČ nájst’ mená: P. Jordan, W. Zsilincsar a F. Žigrai. V zozname renomovaných autorov je možné uviest' aj niektorých geografov z Belgicka (F. Snacken), Francúzska (V. Rey), Holandska (G. J. Ashworth, J. de Vries a J. I. S. Zonneveld), Kanady (M. R. Moss), Rumunska (C. Muica a I. Zavoianu), Slovinska (M. Gabrovec), Svajčiarska (B. Werlen), Talianska (B. Cori) a Spojeného král'ovstva (M. Wood).

\section{REDAKTORSKÁ ČINNOSŤ A REDAKČNÁ RADA}

Počas sledovaného obdobia sa na príprave GČ podiel'alo osem hlavných redaktorov a devät' výkonných redaktorov (tab. 2). Najdlhšie pôsobiacimi hlavnými redaktormi boli riaditelia Geografického ústavu SAV - Emil Mazúr (1965 - 1989), Anton Bezák (1992 - 2006) a Vladimír Ira (2007 - 2018). Náročnú prácu (zodpovedného, resp. výkonného) redaktora najdlhšie vykonávali Jozef Kvitkovič (1961 - 1990), Ján Feranec (1990 - 2006) a Pavel Šuška (2010 - 2018).

Tab. 2. Redaktori Geografického časopisu

\begin{tabular}{|c|c|c|c|}
\hline Rok vydania & Ročník & Hlavný redaktor & Redaktor \\
\hline Geographica Slovaca 1949 & 1 & Mikuláš Bakoš & Mikuláš Konček, Michal Lukniš (zredig.) \\
\hline Zemepisný sborník 1950 & 2 & Mikuláš Konček & \\
\hline Zemepisný sborník 1951 & 3 & Mikuláš Konček & Eduard Šimo (red. tajomník) \\
\hline Zemepisný sborník 1952 & 4 & Mikuláš Konček & \\
\hline GČ 1953 & 5 & Anton Šima & M. Lukniš (zodp.red.), E. Šimo (odb. red.) \\
\hline GČ 1954 & 6 & Anton Šima & Ján Hanzlík \\
\hline GČ $1955-1960$ & $7-12$ & Michal Lukniš & Ján Hanzlík \\
\hline GČ $1961-1964$ & $13-16$ & Michal Lukniš & Jozef Kvitkovič \\
\hline GČ $1965-1989$ & $17-41$ & Emil Mazúr & Jozef Kvitkovič \\
\hline GČ 1990 , č. 1 & 42 & Emil Mazúr & Jozef Kvitkovič \\
\hline GČ 1990, č. 2-4 & 42 & Jozef Kvitkovič & Ján Feranec \\
\hline GČ 1991 & 43 & Jozef Kvitkovič & Ján Feranec \\
\hline GČ $1992-2006$ & $44-58$ & Anton Bezák & Ján Feranec \\
\hline GČ $2007-2009$ & $59-61$ & Vladimír Ira & Anna Grešková \\
\hline GČ 2010 č. 1,2 & 62 & Vladimír Ira & Anna Grešková, Pavel Šuška \\
\hline GČ 2010 č. 3,4 & 62 & Vladimír Ira & Pavel Šuška \\
\hline GČ $2011-2014$ & $63-66$ & Vladimír Ira & Pavel Šuška \\
\hline GČ 2015, č. 1 & 67 & Vladimír Ira & Pavel Šuška \\
\hline GČ 2015, č. 2, 3, 4 & 67 & Vladimír Ira & Pavel Šuška, Daniel Michniak \\
\hline GČ $2016-2018$ & $68-70$ & Vladimír Ira & Pavel Šuška, Daniel Michniak \\
\hline
\end{tabular}


Členovia redakčnej rady sa prvýkrát objavujú na rube titulného listu v roku 1955. V uvedenom roku pôsobilo v redakčnej rade sedem členov z Československa. Na konci kalendárneho roka 2018 mala redakčná rada GČ 26 členov, z toho 12 zo Slovenska, 4 z Česka, 3 z Pol'ska, 3 zo Spojeného král'ovstva, 2 z USA a po jednom členovi z Mad'arska a Rakúska. Členmi redakčnej rady boli významní predstavitelia zahraničných a domácich univerzít a vedecko-výskumných pracovísk a vedeckí pracovníci z Geografického ústavu SAV (pät’ členov).

\section{NAJVIAC ZASTÚPENÉ TÉMY V ČLÁNKOCH UVEREJNENÝCH $\mathrm{V}$ GEOGRAFICKOM ČASOPISE}

Minulé pokusy porozumiet' „systému geografie“ sa vo vel'kej miere zakladali, či už explicitne alebo implicitne, na filozofických poznatkoch jednotlivých pracovníkov v odbore. Súvisiaca analýza niekedy vyvolala dojem, že geografia musí byt' vysoko multidichotomická (Smith 2013). Citovaný autor vychádzal zo skúseností v minulosti, ked' nebolo možné nájst' konsenzsus pri vnútornom členení systému geografie. V dotazníkovom výskume uskutočnenom na náhodnej vzorke medzi členmi Asociácie amerických geografov (AAG) zhromaždil informácie, ktoré sa stali podkladom na zostavenie klasifikačného obrazu „systému“ geografie. Vo výskume bol použitý zoznam 60 subdisciplín, resp. oblastí výskumu. Vychádzajúc zo skúseností uvedeného výskumu sme v našej analýze použili množinu 38 subdiciplín, resp. oblastí, ktoré sme podrobili časovej analýze.

Tab. 3 Najviac zastúpené subdisciplíny, témy, resp. oblasti výskumu

\begin{tabular}{cl}
\hline Časové obdobie & \multicolumn{1}{c}{ Najviac zastúpené subdisciplíny, témy (oblasti) v publikovaných článkoch } \\
\hline \multirow{2}{*}{$1949-1968$} & $\begin{array}{l}\text { geomorfológia, pedogeografia, klimatológia a meteorológia, hydrogeografia, historická } \\
\text { geografia } \\
\text { geomorfológia, pedogeografia, klimatológia a meteorológia, hydrogeografia, biogeografia, }\end{array}$ \\
& $\begin{array}{l}\text { geoekológia a komplexná FG, urbánna geografia, environmentálna geografia, regionálna } \\
\text { geografia a regionalizácia, teoretická geografia, kartografia }\end{array}$ \\
& $\begin{array}{l}\text { geomorfológia, klimatológia a meteorológia, hydrogeografia, geoekológia a komplexná } \\
\text { FG, geografia obyvatel'stva a demogeografia, urbánna geografia, sociálna geografia, } \\
\text { politická geografia, environmentálna geografia, využitie zeme a krajinná pokrývka, } \\
\text { teoretická geografia, kartografia, GIS - DPZ a geoinformatika, metódy a dáta } \\
\text { geomorfológia, pedogeografia, klimatológia a meteorológia, hydrogeografia, } \\
\text { geoekológia a komplexná FG, geografia obyvatel'stva a demogeografia, sídelná } \\
\text { geografia (najmä urbánna), teoretická geografia, historická } \\
\text { geografia, kartografia, metódy a dáta }\end{array}$ \\
\hline
\end{tabular}

Poznámka: boldom vyznačené subdisciplíny (oblasti) boli zastúpené vo významnej miere vo všetkých troch analyzovaných obdobiach

Časové členenie našej analýzy vychádza zo zlomových období, ked' došlo k výrazným politickým a spoločensko-ekonomickým zmenám (tab. 3). Predpokladáme, že v týchto obdobiach nastali aj výraznejšie zmeny v geografickom myslení (niekedy azda aj diskontinuity), ktoré sa výraznejšie prejavili aj v charaktere publikovaných článkov. Prvé obdobie predstavuje tri dekády od založenia časopisu až do roku 1968. Druhé obdobie sa začína rokom 1969, ked' postupne dochádzalo k výraznejšej regulácii a cenzúre publikácií. Obdobie skoršej a neskoršej „normalizácie“" poznačilo geografické publikácie čiastočnou autocenzúrou, obmedzením tematických okruhov výskumu a väčšou uzavretost’ou v rámci krajín sovietskeho 
bloku. Podrobnejšia analýza ukazuje, že v geografii (dokonca aj vtedajšej sociálnoekonomickej) reštrikcie vd’aka hlavnému redaktorovi a redakčnej rade GC neboli príliš výrazné. Tretie, takmer tridsat'ročné obdobie sa začína rokom 1990, ked' na jednej strane došlo k výrazným politickým a spoločenským zmenám v ČeskoSlovensku a v strednej a východnej Európe spojeným s postupnou transformáciou spoločnosti, na druhej strane vo svete pomerne rýchlo nastupujú výrazné zmeny globálneho charakteru a zmeny v oblasti informačných a komunikačných technológií. Uvedené zmeny ovplyvnili charakter a smerovanie geografického výskumu nielen v (Česko-)Slovensku, ale aj v širších medzinárodných kontextoch.

V prvých dvoch dekádach boli dominantne zastúpené fyzicko-geografické subdisciplíny - geomorfológia (morfogeografia), pedogeografia, klimatológia (klimageografia) a meteorológia, hydrogeografia a napokon historická geografia (Martinka 1956). V období po roku 1968 do roku 1989 boli opät najviac zastúpené príspevky z geomorfológie, pedogeografie, klimatológie a meteorológie, hydrogeografie, biogeografie a historickej geografie (napr. Žudel 1974). Vd’aka novoformujúcej sa geoekologickej škole v Geografickom ústave SAV sa objavujú príspevky z geoekológie a komplexnej fyzickej geografie (Huba 1982 a Mazúr et al. 1983). Celosvetový záujem o problematiku životného prostredia sa odrazil aj v publikačných aktivitách autorov zameraných na environmentálnu geografiu (Drdoš 1978 a Urbánek et al. 1980). Aktivity spojené s atlasovou tvorbou (najmä prípravou a vydaním Atlasu SSR - Jakál 1978), otázky regionálnej geografie a regionalizácie (Bašovský 1986), geografie cestovného ruchu (Mariot 1971) a geografie maloobchodu (Očovský 1977) sa v tomto období objavili v GČ. Systematická pozornost' sa venovala aj problémom kartografie, resp. mapy ako jazyka, ktorý má pri riešení priestorových problémov nezastupitel'nú funkciu. Vo všeobecnej rovine sa tomuto problému venoval J. Pravda (1985). Teoretickým problémom geomorfologického mapovania sa venoval v skoršom období napr. Mazúr (1963) a neskôr napr. Urbánek (1997) a Minár (1998). Narastajúca urbanizácia a industrializácia (Mládek 1986), problémy miest boli vo zvýšenej miere témou urbánno-geografických príspevkov. Vd'aka viacerým slovenským i zahraničným autorom sa začali objavovat' aj príspevky z teoretickej geografie (napr. Mičian 1971, Urbánek et al. 1980). Obdobie po roku 1989 je charakteristické výrazným rozširovaním tematických okruhov publikovaných článkov. Profil GČ , charakterizovaný štruktúrou publikovaných článkov, sa vd’aka novým geograficky relevantným globálnym a regionálnym javom, ale aj v dôsledku výrazného pokroku v informačných technológiách a výskumných metódach i slobodným bádatel'ským pomerom, väčšej otvorenosti voči svetu a hlbšej reflexii zmien v geografickom myslení vo svete do značnej miery zmenil. Okrem pretrvávajúceho záujmu publikovat' príspevky z geomorfológie (napr. Stankoviansky 1992, alebo Lehotský a Grešková 2007 s novými témami z oblasti fluviálnej geomorfológie), klimatológie a meteorológie, hydrogeografie a geoekológie, autori venujú pozornost' aj d’alším tradičným oblastiam - geografii obyvatel'stva a demogeografii (napr. Podolák 1993) a urbánnej geografii (predovšetkým transformácii urbánnych štruktúr a suburbanizácii - napr. Ondoš a Korec 2008 a Šveda 2011). Celý rad aktuálnych problémov, ktoré priniesla postsocialistická transformácia, sa stáva témou bádania $\mathrm{v}$ humánnej a regionálnej geografii. Podobne, ako konštatujú Korec a Rusnák (2018), tento trend badat’ aj v obsahu príspevkov v GČ. Pozornost' sa venuje regionálnym rozdielom, novej hierarchickej organizácii štátu, nezamestnanosti a jej regionálnej diferencovanosti, dostupnosti (Michniak 2003), mobilite a migrácii, kvalite života (Ira a Andráško 2007) a jej 
meraniu, starnutiu obyvatel'stva (Mládek a Káčerová 2008), chudobe (Michálek 2000), kriminalite a jej priestorovým aspektom (Michálek 1995). Objavujú sa aj témy zamerané na maloobchod a zmeny spotrebitel'ského správania, nové formy cestovného ruchu, priame zahraničné investície a d'alšie. Politická geografia je reprezentovaná predovšetkým štúdiami zameranými na volebnú geografiu (Baráth et al. 1995), environmentálna geografia príspevkami venovanými udržatel'nosti (napr. Huba a Ira 1996 a Hanušin et al. 2008). Dynamický vývoj spoločnosti spojený s ekonomickou transformáciou zaujal aj množstvo autorov, ktorí zamerali svoje vedecké články na problematiku zmien využitia zeme a krajinnej pokrývky (napr. Ot’ahel' a Feranec 1997). Cenné poznatky sa objavili v príspevkoch orientovaných na témy z teoretickej geografie (napr. Urbánek 1992, Mičian 1999, Minár 2009 a Paulov 2012), kartografie, GIS (Mičietová 1999), DPZ (Š́ri 1991) a geoinformati$\mathrm{ku}$.

\section{DISKONTINUITY V SVETOVOM GEOGRAFICKOM MYSLENÍ A ICH ODRAZ V PUBLIKÁCIÁCH UVEREJNENÝCH $\mathrm{V}$ GEOGRAFICKOM ČASOPISE}

Na vývoj geografického myslenia, tak ako bol prezentovaný v článkoch GČ, je možné pozriet' sa cez koncepčný rámec výskumu zameraného na diskontinuity vo vedeckom myslení a jeho recepciu v geografii, tak ako ho formulovali v svojej štúdii Matlovič a Matlovičová (2020). Kuhn (1997) konceptualizoval diskontinuitu ako vedeckú revolúciu v podobe paradigmatického posunu, ktorú chápal ako rozhodujúcu kvalitatívnu transformáciu ontologickej, metodologickej a axiologickej úrovne vednej disciplíny. Podl'a Kuhna sa vývoj vednej disciplíny, ktorá dosiahla určitú úroveň zrelosti, teda paradigmatického štádia, deje podl'a 3-fázového cyklického modelu: obdobie normálnej vedy (dominancie určitej paradigmy) - obdobie vedeckej krízy - obdobie vedeckej revolúcie - obdobie novej normálnej vedy (dominancia novej paradigmy). Vedecká revolúcia je výsledkom určitej krízy vednej disciplíny, ktorú nie je možné vyriešit' existujúcou paradigmou a úpravami jej teórií.

Počiatky moderného geografického myslenia na Slovensku súvisia predovšetkým s francúzskou školou regionálnej geografie, ktorej koncepcie uplatnil J. Hromádka pri syntéze regionálnej geografie. Jej „,dozvuky“ možno badat' ešte v prvých článkoch časopisu.

Od začiatku 50. rokov 20. storočia sa práce v analyzovanom periodiku začínajú odklán̆at' od tejto paradigmy $\mathrm{v}$ dôsledku prechodu na paradigmu dialektického a historického materializmu motivovaného sovietizáciou univerzitného školstva a vedeckého výskumu. V šesdesiatych rokoch 20 . storočia sa v publikáciách prejavovali tendencie komplexných prístupov (rozvoj komplexnej fyzickej geografie a štúdium teritoriálnych komplexov v ekonomickej geografii) a snažili sa reagovat' na potrebu vypracovania metód a spôsobov spracovania územnej regionalizácie (Ivanička 1965).

Napriek tomu, že táto paradigma bola záväzná až do obdobia spoločenskopolitických zmien na prelome rokov 1989 a 1990, viacerým autorom sa podarilo reflektovat' takmer všetky príslušné diskontinuity daného obdobia. Kvantitatívna diskontinuita (orientácia na problémy kvantitatívnej geografie) sa prejavila desat'ročie po jej založení v západnej geografii. Prvou reflexiou kvantitatívnej diskontinuity v slovenskej geografii bola práca Paulova (1966). Vd'aka nemu geografia na Slovensku pomerne skoro zachytila kvantitatívnu diskontinuitu vo svetovej geogra- 
fii. Okrem Paulova paradigmu geografie ako priestorovej vedy v GČ reflektovali aj Krcho (1968), Bezák (1975) a Poláčik (1977). Ako uvádzajú Matlovič a Matlovičová (2020), po prijatí kvantitatívnej diskontinuity geografía na Slovensku reagovala pomerne skoro aj na systémovú a komplexnú diskontinuitu. Systémový prístup sa aplikoval predovšetkým vo fyzicko-geografickom výskume. Geosystémový prístup a inšpirácie $z$ diela britského geografa P. Haggetta „Geografia a moderná syntéza" sa použili pri tvorbe koncepcie krajinnej syntézy (Mazúr et al. 1983). Jej tvorivé prepojenie s tzv. „landšaftnou školou“" prinieslo mnoho cenných výsledkov a vznik medzinárodne uznávanej bratislavskej školy krajinnej syntézy.

Behaviorálna diskontinuita priniesla prvé reakcie v rámci slovenskej geografickej komunity už polovici 70 . rokov 20 . storočia. Prvé práce v tejto oblasti boli zamerané na vnímanie a hodnotenie kvality životného prostredia. V GČ reflektoval aspekty vnímania pri výskume obrazu mesta Radváni (1983). Tento prúd geografického myslenia sa však podarilo rozvinút' na stránkach časopisu až v 90. rokoch. Príkladom sú práce Kollára (1992), Iru (1994) a d’alších.

Postpozitivistická diskontinuita iniciovala prvú reflexiu v príspevku J. Paulova (1986) ktorý vyšiel na stránkach GČ. Možno v tejto súvislosti spomenút' aj článok od autorov Rochovská et al. (2007), ktorí ako prví v GČ explicitne zdôraznili dôležitost' kvalitatívneho výskumu v humánnej geografii. Postpozitivistická diskontinuita bola spojená s reflexiou humanistickej diskontinuity.

Vedecko-realistická nová regionalistická a feministická diskontinuita spôsobila pomerne skromnú reakciu. O štruktúrnej diskontinuite, kultúrnej diskontinuite a koncepciách novej kultúrnej geografie sa v slovenskej geografii zatial' nehovorí (Matloviča a Matlovičová 2020). Postmoderná diskontinuita sa premietla do súhrnných štúdií a v slovenskej geografickej literatúre nájdeme aj prvé aplikácie konceptov ako výsledok postštrukturalistickej relačnej diskontinuity. Postkoloniálne a posthumanistické diskontinuity boli iba informatívne diskutované mimo GČ v širších prehl'adoch geografického myslenia (Matlovič a Matlovičová 2015). Vo všeobecnosti zostáva potenciál postmodernej postštrukturalistickej geografie v geografických publikáciách na Slovensku (vrátane GČ) využívaný iba minimálne (Matlovič a Matlovičová 2020).

\section{OHLASY NA ČLÁNKY V GEOGRAFICKOM ČASOPISE VO SVETOVÝCH CITAČNÝCH DATABÁZACH}

$\mathrm{V}$ tejto časti nášho príspevku sa zameriame na hodnotenie článkov v GČ prostredníctvom citácií. Citácie sú chápané ako jeden z prostriedkov, ktoré umožňujú hodnotit' nielen kvalitu a uznanie vedeckej práce, ale sú dôležitým nástrojom vyhl'adávania informácií. Ich uvádzanie patrí k základným otázkam etiky písania vedeckých prác. Bibliografická citácia alebo citácia je technika (metóda a spôsob) spojenia bibliografického odkazu s miestom textu, ku ktorému sa vzt’ahuje bibliografický odkaz (Katuščák 2005). Citácia slúži na spojenie citovaného miesta so záznamom o citovanom dokumente. Tento záznam je potom položkou v zozname bibliografických odkazov - zoznam literatúry a referencie (Kimlička 2002).

V našom skúmaní sme sa zamerali na štatistiku počtu citácií GČ, ktoré sú zaznamenané vo svetových citačných databázach Web of Science a Scopus. Oba elektronické zdroje - Web of Science Core Collection (d'alej WOS) a Scopus predstavujú bibliografické citačné multidisciplinárne databázy. Poskytujú prístup k spracovaným záznamom z vybraných zdrojov (vedecké časopisy, konferenčné 
príspevky, knihy a zborníky). Pokrývajú celé spektrum vedeckých odborov a sledujú väzby medzi publikáciami na základe citačných prameňov. Umožňujú štatistickú analýzu citácií časopiseckých titulov, autorov a ich vzájomné porovnanie na základe scientometrických metód.

V prvej časti príspevku bola uvedená informácia o tom, že GČ je indexovaný v databáze Scopus. Prvá perióda indexovania bola v rokoch 1979 - 1995, druhá prebieha od roku 2007 doteraz. V praxi to znamená, že všetky články z uvedených rokov sú spracované formou bibliografických záznamov a abstraktov, pri niektorých je možnost' zobrazenia aj plného textu (otvorený prístup) a sú k nim prirad'ované citácie. Aj ked' v databáze WOS náš časopis dodnes nie je registrovaný a indexovaný, je tu možnost' vyhl'adania citácií GČ (tzv. sekundárne citácie).

Metodika vyhl'adávania citácií bola $\mathrm{v}$ oboch databázach odlišná. $\mathrm{V}$ databáze WOS sme hl'adanie uskutočnili prostredníctvom vol'by cited reference search. Zadaním pol'a citovaná práca (cited search) - Geograficky casopis a roku vydania (cited year) sme sa dopracovali k výstupu neaktivovaných záznamov nášho časopisu aj s počtom citácií. Aby sme vylúčili autocitácie, bolo nevyhnutné vojst' do každého záznamu citácie a osobitne kontrolovat' autorov. Okrem celého názvu Geografický časopis sme v databáze overovali aj skrátený názov uvádzaný pod termínom ,Geogr cas“.

Metodika hl'adania citácií GČ v databáze Scopus bola jednoduchšia. V základnej možnosti Search v poli vyhl'adávania zdrojový dokument - Source title sme zvolili názov Geograficky casopis a limitovali sme si postupne roky hl'adania. V rokoch, ked' bol časopis v databáze indexovaný, bola výsledkom množina článkov s citáciami. V ostatných neregistrovaných rokoch sa nám síce žiadne záznamy nezobrazili, ale v tomto kroku sa objavila možnost' hl'adat' sekundárne dokumenty (view secondary documents). Jej použitím sme sa dopracovali aj k záznamom s citáciami pri chýbajúcej indexácii čísiel časopisu. V d’alších krokoch bolo potrebné postupovat' ako v databáze WOS, zobrazit' si citácie a vylúčit autocitácie. V oboch databázach sme sa stretli pri hl'adaní citácií s formálnymi chybami pri spracovávaní záznamov (neúplné názvy časopisu, preklepové chyby a pod.).

Dovol'ujeme si upozornit', že počet citácií nemusí byt' stopercentne presný najmä z dôvodu chybovosti spracovatel'ov záznamov a možných skratiek názvu časopisu. Pred porovnaním štatistických výsledkov z oboch databáz, sme predpokladali výrazne vyššie číslo počtu citácií v databáze Scopus vzhl'adom na indexovanie článkov, ale naša hypotéza sa nepotvrdila. Č́sla citácií v databáze WOS tvorili takmer 92 \% z čísiel citácií v Scopuse. Predpokladáme, že to bude v širšom obsahovom a časovom zábere spracovávaných titulov periodík v databáze WOS.

Výsledkom nášho vyhl'adávania za sledovanné obdobie bolo 1226 záznamov v databáze WOS, ktoré citujú články v GČ a 1336 záznamov v databáze Scopus (výsledky spracovania sa viažu k dátumu 25. marec 2019). Štatistický prehl'ad citácií uvádzame podl'a jednotlivých rokov (tab. 4), dekád (obr. 1) a troch analyzovaných období (tab. 5), v ktorých časopis vychádzal. Z údajov v tabul'ke 4 je zrejmé, že články v GČ publikované v roku 1958 neboli vôbec citované. Citácie príspevkov uverejnených v roku 2018 nemali ohlasy v čase vyhl'adávania. Predpoklad citovania článkov $\mathrm{v}$ d’alšom časovom období potvrdzujú údaje $\mathrm{z}$ druhého polroku 2020, kde bolo zaznamenaných viac citácií v databáze Scopus a WOS.

V nasledujúcich riadkoch uvádzame tri najcitovanejšie články GČ v oboch databázach. V databáze WOS sme zaznamenali 23 citácií článku Mazúra a Lukniša 
(1978) Regionálne geomorfologické členenie SSR a 19 citácií štúdie Bezáka (1990) Funkčné mestské regióny v sídelnom systéme Slovenska. Tretím najcitovanejším článkom (16 citácií) bolo Regionálne členenie Slovenskej socialistickej republiky z hl'adiska jej racionálneho rozvoja (Lukniš 1985). Najvyšší ohlas v databáze Scopus s počtom 31 citácí́ sme zaznamenali pri článku Mapovanie krajinnej pokrývky metódou CORINE v mierke 1:50 000: návrh legendy pre krajiny programu Phare (Feranec a Ot’ahel' 1999) a príspevku Mazúra a Lukniša (1978), Regionálne geomorfologické členenie SSR - 21 citácií. Pri štúdii Kvalita života z pohl'adu humánnej geografie (Ira a Andráško 2007) bolo evidovaných 17 citácií. V sedemdesiatych a osemdesiatych rokoch 20 . stor. boli najcitovanejšie práce zamerané na regionálne členenie Slovenska (geomorfologické a z hl'adiska rozvoja). Od roku 1990 boli medzi najcitovanejšími štúdiami práce zaoberajúce sa problematikou funkčných mestských regiónov, zmien krajinnej pokrývky a geografickými aspektami kvality života.

Tab. 4. Citácie publikácií v GČ v databázach WOS a Scopus v rokoch 1949 - 2018 (bez autocitácií)

\begin{tabular}{rrrrrrrrr}
\hline Rok & WOS cit. & SCOPUS cit. & Rok & WOS cit. & SCOPUS cit. & Rok & WOS cit. & SCOPUS cit. \\
\hline 1949 & 3 & 0 & 1973 & 18 & 11 & 1997 & 6 & 7 \\
1950 & 1 & 2 & 1974 & 14 & 19 & 1998 & 12 & 12 \\
1951 & 3 & 0 & 1975 & 8 & 7 & 1999 & 35 & 47 \\
1952 & 1 & 1 & 1976 & 9 & 11 & 2000 & 44 & 51 \\
1953 & 2 & 1 & 1977 & 8 & 5 & 2001 & 48 & 47 \\
1954 & 3 & 1 & 1978 & 31 & 29 & 2002 & 19 & 14 \\
1955 & 10 & 7 & 1979 & 1 & 6 & 2003 & 37 & 29 \\
1956 & 9 & 3 & 1980 & 19 & 27 & 2004 & 21 & 30 \\
1957 & 6 & 3 & 1981 & 8 & 12 & 2005 & 39 & 38 \\
1958 & 0 & 0 & 1982 & 4 & 9 & 2006 & 40 & 35 \\
1959 & 2 & 3 & 1983 & 23 & 29 & 2007 & 48 & 55 \\
1960 & 3 & 6 & 1984 & 7 & 19 & 2008 & 51 & 64 \\
1961 & 8 & 3 & 1985 & 25 & 32 & 2009 & 54 & 44 \\
1962 & 10 & 1 & 1986 & 12 & 26 & 2010 & 46 & 45 \\
1963 & 5 & 0 & 1987 & 7 & 10 & 2011 & 52 & 65 \\
1964 & 43 & 33 & 1988 & 9 & 17 & 2012 & 30 & 38 \\
1965 & 9 & 9 & 1989 & 14 & 15 & 2013 & 27 & 49 \\
1966 & 6 & 1 & 1990 & 40 & 26 & 2014 & 47 & 58 \\
1967 & 20 & 12 & 1991 & 9 & 9 & 2015 & 21 & 26 \\
1968 & 11 & 9 & 1992 & 23 & 30 & 2016 & 9 & 14 \\
1969 & 7 & 1 & 1993 & 14 & 17 & 2017 & 1 & 4 \\
1970 & 2 & 3 & 1994 & 15 & 26 & 2018 & 0 & 0 \\
1971 & 12 & 11 & 1995 & 20 & 35 & & & \\
1972 & 8 & 7 & 1996 & 17 & 20 & & &
\end{tabular}

Tab. 5. Citácie publikácií v GČ v databázach WOS a Scopus analyzované v troch obdobiach medzi rokmi 1949 a 2018 (bez autocitácií)

\begin{tabular}{ccccc}
\hline Obdobia & Citácie WOS & $\begin{array}{c}\text { Priemerný počet } \\
\text { citácií WOS/rok }\end{array}$ & Citácie Scopus & $\begin{array}{c}\text { Priemerný počet citácií } \\
\text { Scopus/rok }\end{array}$ \\
\hline $1949-1968$ & 155 & 7,8 & 95 & 4,8 \\
$1969-1989$ & 246 & 11,7 & 306 & 14,6 \\
$1990-2018$ & 825 & 26,6 & 955 & 30,8 \\
Spolu $1949-2018$ & 1226 & 17,5 & 1336 & 19,1 \\
\hline
\end{tabular}




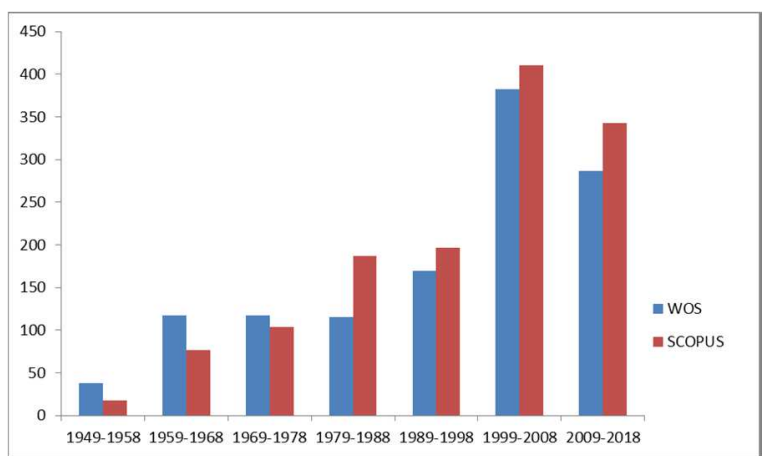

Obr. 1. Citácie publikácií v GČ v databázach WOS a Scopus (1949 - 2018)

\section{POROVNANIE SCIENTOMETRICKÝCH ÚDAJOV O GEOGRAFICKOM ČASOPISE A VYBRANÝCH GEOGRAFICKÝCH PERIODIKÁCH}

Články a štúdie vo vedeckých časopisoch predstavujú dôležitý komunikačný kanál, informácie v nich sú vyhl'adávané pre svoju dostupnost', rýchlost' a šírenie originálnych vedeckých poznatkov. Na hodnotenie kvality periodík používame nástroje databázových produktov (WOS a Scopus), ktoré využívajú citačnú analýzu.

Citačná analýza vedeckých publikácií je oblast’ scientometrie, ktorá skúma vzt’ahy medzi citovanými a citujúcimi dokumentami na základe analýzy početnosti citácií a bibliografických odkazov. Vzt'ahy môžu byt' skúmané nielen na úrovni dokumentov, ale aj na úrovni autorov, časopisov, inštitúcií alebo vedných oblastí (Rousseau 2008). Predmetom skúmania citačnej analýzy sú teda citácie, resp. bibliografické odkazy. Napriek tomu, že sa vo vedeckej komunite vedú polemiky ohl'adom objektívnosti citácií a kvantitatívneho aspektu citačnej analýzy, scientometrické metódy (citačné indexy) sa stali uznávanými a rozšírenými nástrojmi na porovnávanie kvality publikácií $\mathrm{v}$ rámci jednotlivých odborov na celom svete. Scientometria predpokladá, že počet citácií dokumentu odráža jeho význam a kvalitu a ku kvalite sa dostávame cez kvantitatívne analýzy a merania.

V prípade nasledujúceho hodnotenia GČ a vybraných periodík (tab. 6) sa zameriame na kvantitatívne indikátory používané v databáze Scopus. Výber časopisov vychádzal z podmienky, že články sú indexované v tejto databáze. Scopus je spoplatnená, multidisciplinárna bibliografická abstraktová, citačná a referenčná databáza, ktorá je jednou najvýznamnejších databáz svojho druhu na svete. Bola spustená do prevádzky v roku 2004 holandskou spoločnostou Elsevier. Stáva sa čoraz väčšou konkurenciou dominujúcej bibliografickej databázy Web of Science v súčasnosti prevádzkovanej spoločnost'ou Clarivate Analytics (predtým Thomson Reuters).

Rozpis kategórií v databáze Scopus (Scimago Journal Rank), do ktorých boli zaradené hodnotené časopisy (tab. 7), poukázal, že časopisy (okrem 4 titulov) sú zaradené do viacerých kategórií. Išlo predovšetkým o zaradenie periodík do oblasti Earth and Planetary Sciences a Social Sciences. Všetky analyzované tituly, okrem jedného pol'ského časopisu (Questiones Geographicae), sú zaradené do kategórie Geography, Planning and Development. Rozbor a kvantifikovanie scientometrických údajov (kvartily časopisov) sme uskutočnili na základe troch kategórií, do 
ktorých je zaradená väčšia čast' nami vybraných časopisov. Ide o už spomínané kategórie Geography, Planning and Development, ako aj kategórie Earth and Planetary Sciences (miscellaneous) a Earth Surface Processes.

Tab. 6. Hodnotené periodiká podl’a krajín

\begin{tabular}{|c|c|}
\hline Krajina & Názov časopisu \\
\hline Česko &  \\
\hline Chorvátsko & Hrvatski Geografski Glasnik \\
\hline Mad'arsko & Hungarian Geographical Bulletin \\
\hline Pol'sko & $\begin{array}{c}\text { Bulletin of Geography - socio-economic series (WOS*) } \\
\text { European Spatial Research and Policy (WOS*) } \\
\text { Geographia Polonica (WOS*) } \\
\text { Quaestiones Geographicae (WOS*) }\end{array}$ \\
\hline Rakúsko & Mitteilungen der Österreichischen Geographischen Gessellschaft (WOS*, CCC**, JCR***) \\
\hline Rumunsko & $\begin{array}{l}\text { Geographia Technica (WOS*) } \\
\text { Human Geographies } \\
\text { Revue Roumaine de Geographie }\end{array}$ \\
\hline Slovensko & $\begin{array}{c}\text { Geografický časopis } \\
\text { Geographia Cassoviensis (WOS*) }\end{array}$ \\
\hline Slovinsko & $\begin{array}{l}\text { Acta Geographica Slovenica } \\
\text { Geografski Vestnik }\end{array}$ \\
\hline Srbsko & Geographica Pannonica \\
\hline
\end{tabular}

Poznámka: WOS* - databáza Web of Science Core Collection

CCC**_databáza Current Context Connect (karentované časopisy)

JCR*** - Journal Citation Report (impaktované časopisy)

V d'alšej fáze po selekcii sme sa už zamerali na výber konkrétnych scientometrických údajov z databázy v časovom rozpätí pät' rokov (2013 - 2017): kvartily časopisov, indikátor SJR a indikátor SNIP. Hodnoty scientometrických údajov v databáze Scopus sme overovali na vol'ne dostupnom portáli Scimago Journal Rank, ako aj priamo v databáze Scopus.

Kvartily časopisov - rozdel'ujú poradie časopisov na kvalitatívne pásma, ide o rozdelenie množiny časopisov vo vybranej kategórii na štvrtiny (I. kvartil zahŕňa $25 \%$ najlepších časopisov podl'a údajov SJR, posledný IV. kvartil $25 \%$,najhorších časopisov"). Časopis môže byt' zaradený do viacerých kategórií s rôznymi kvartilmi.

SCImago Journal Rank Indicator (SJR) - táto metrika hodnotenia vychádza z myšlienky, že všetky citácie nie sú rovné. Hodnotu citácie priamo ovplyvňuje odbor, kvalita a renomovanost' časopisu. Meria vedecký vplyv časopisov a berie do úvahy počet citácií, ktoré časopis získal, ako aj dôležitost' alebo prestíž časopisu, odkial' citácie pochádzajú. Vyjadruje priemerný počet vážených citácií v aktuálnom roku na publikácie vydané v predchádzajúcich troch rokoch. Výpočet je založený na zložitom algoritme. Táto metrika zaručuje, že finálne číslo SJR môže byt' 
indikátorom na porovnanie kvality časopisov aj $\mathrm{z}$ iných vedeckých disciplín (porovnávanie časopisov v rôznych vedných odboroch).

\section{Tab. 7. Odborné kategórie časopisov}

\begin{tabular}{|c|c|c|}
\hline $\begin{array}{l}\text { Geography, Planning } \\
\text { and Development }\end{array}$ & $\begin{array}{l}\text { Earth and Planetary Sciences } \\
\text { (miscellaneous) }\end{array}$ & Earth Surface Processes \\
\hline Acta Geographica Slovenica & \multirow{20}{*}{$\begin{array}{l}\text { Acta Geographica Slovenica } \\
\text { AUC Geographica } \\
\text { Geographia Cassoviensis } \\
\text { Geographia Polonica } \\
\text { Hungarian Geographical Bulletin } \\
\text { Moravian Geographical Reports } \\
\text { Quaestiones Geographicae }\end{array}$} & \multirow{20}{*}{$\begin{array}{l}\text { Geografický časopis } \\
\text { Geografie - Sborník České } \\
\text { Geografické společnosti } \\
\text { Geografski vestnik } \\
\text { Geographia Technica } \\
\text { Geographica Pannonica } \\
\text { Hrvatski Geografski Glasnik } \\
\text { Mitteilungen } \\
\text { der Österreichischen } \\
\text { Geographischen Gessellschaft }\end{array}$} \\
\hline AUC Geographica & & \\
\hline Bulletin of Geography - & & \\
\hline socio-economic series & & \\
\hline European Spatial Research and & & \\
\hline Policy & & \\
\hline Geografický časopis & & \\
\hline $\begin{array}{l}\text { Geografie - Sborník České } \\
\text { Geografické společnosti }\end{array}$ & & \\
\hline Geografski vestnik & & \\
\hline Geographia Cassoviensis & & \\
\hline Geographia Polonica & & \\
\hline Geographia Technica & & \\
\hline Geographica Pannonica & & \\
\hline Hrvatski Geografski Glasnik & & \\
\hline Human Geographies & & \\
\hline Hungarian Geographical Bulletin & & \\
\hline $\begin{array}{l}\text { Mitteilungen der Österreichischen } \\
\text { Geographischen Gessellschaft }\end{array}$ & & \\
\hline Moravian Geographical Reports & & \\
\hline Revue Roumaine de Geographie & & \\
\hline Quaestiones Geographicae & & \\
\hline
\end{tabular}

Poznámka: časopisy, ktoré boli zaradené aj v iných kategóriách - Bulletin of Geography (Cultural Studies; Demography; Urban Studies), Geografický časopis (Geology), Geographia Technica (Computers in Earth Sciences), Geographica Pannonica (Tourism, Leisure and Hospitality Management, Atmospheric Science, Geology).

Source Normalized Impact per Paper (SNIP) - meria citačný impakt pomocou váženej hodnoty citácie podl'a celkového počtu citácií $v$ danej vednej oblasti (porovnávanie časopisov v odbore). Tento ukazovatel' hodnotí citačné údaje časopisu podl'a jednotlivých vedeckých odborov, teda berie do úvahy špecifiká vednej oblasti, a to: citačnú frekvenciu, pokrytie oblasti citačnou databázou, rýchlost', akou publikácie získavajú vplyv (ako rýchlo začnú byt' citované), vednú oblast' tvorenú množinou časopisov, ktoré daný časopis citujú (Ondrišová 2011 a Fabián 2012).

Nasledujúce grafy (obr. 2, 3, 4 a 5) sú spracované na základe údajov z databázy Scopus a z portálu Scimago Journal Rank. Na báze uvedených scientometrických údajov môžeme konštatovat', že medzi sledovanými časopismi nie sú vel'mi výrazné rozdiely. Z hl'adiska kvantitatívnych ukazovatel'ov sa ako najlepší časopis v sledovanom období prezentoval Moravian Geographical Reports z Česka, ktorý sa 
v roku 2016 dostal do kategórie časopisov zaradených v I. kvartile. O jeho kvalite svedčí aj fakt, že je zároveň karentovaný a impaktovaný v databáze WOS. Jeho vzostup je výrazný najmä v ostatných rokoch. Medzi prvú polovicu množiny časopisov v kategórii Geography, Planning and Development (II. kvartil) sa dostali aj d'alšie tituly: Acta Geographica Slovenica, AUC Geographica, Geografický časopis, Geografie - Sborník CGS, Geographia Polonica a v roku 2017 aj časopis Hungarian Geographical Buletin. Na základe kvantitatívnej citačnej analýzy možno konštatovat', že GČ si v ostatných rokoch drží pomerne stabilnú úroveň. V nasledujúcom období možno očakávat' zo strany redakcie časopisu iniciatívy smerujúce k zvýšeniu publikovania hodnotných článkov a získavaniu článkov na publikovanie od kvalitných renomovaných domácich i zahraničných autorov. Táto plánovaná stratégia má predpoklad priniest' dobré výsledky aj v ohlasoch na publikácie a znamenala by skvalitnenie výsledkov aj v scientometrických údajoch.

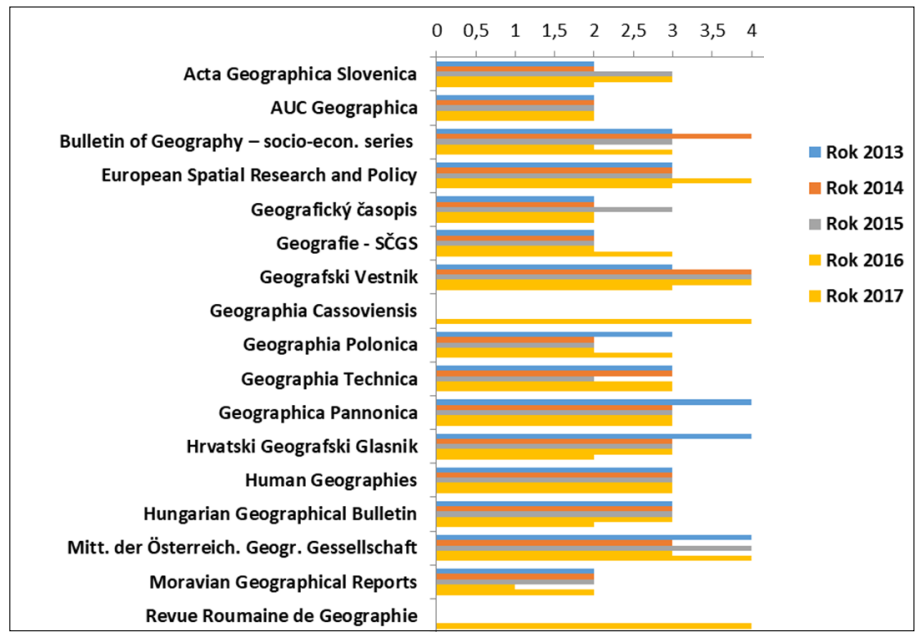

Obr. 2. Zaradenie časopisov podla kvartilov v kategórii Geography, Planning and Development (množina 699 titulov)

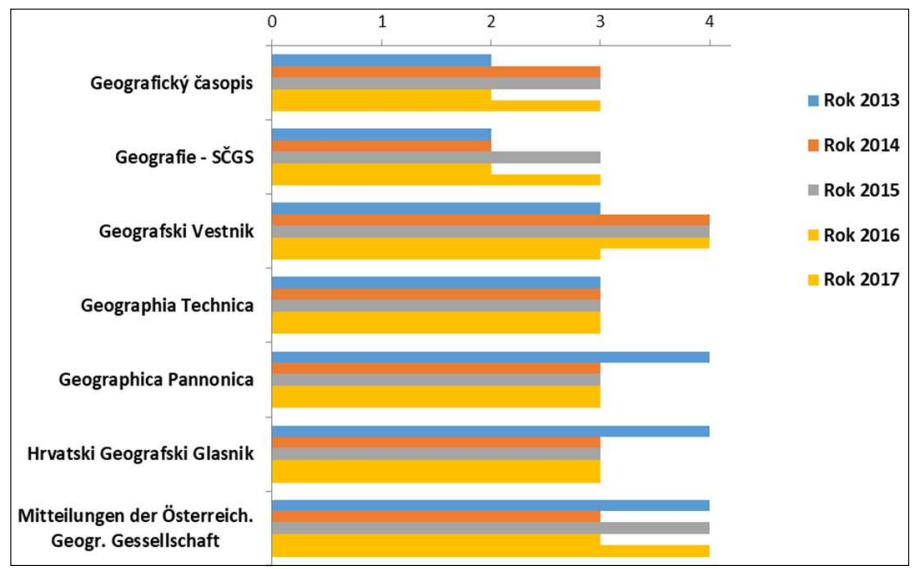

Obr. 3. Zaradenie časopisov podl'a kvartilov v kategórii Earth Surface Processes (množina 154 titulov) 


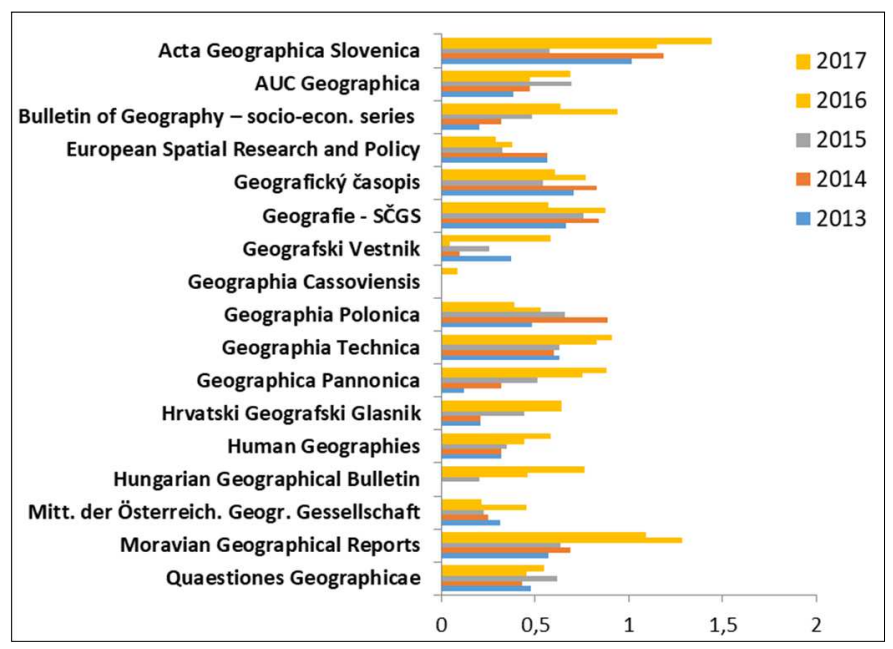

Obr. 4. Index SNIP analyzovaných časopisov (2013 - 2017)

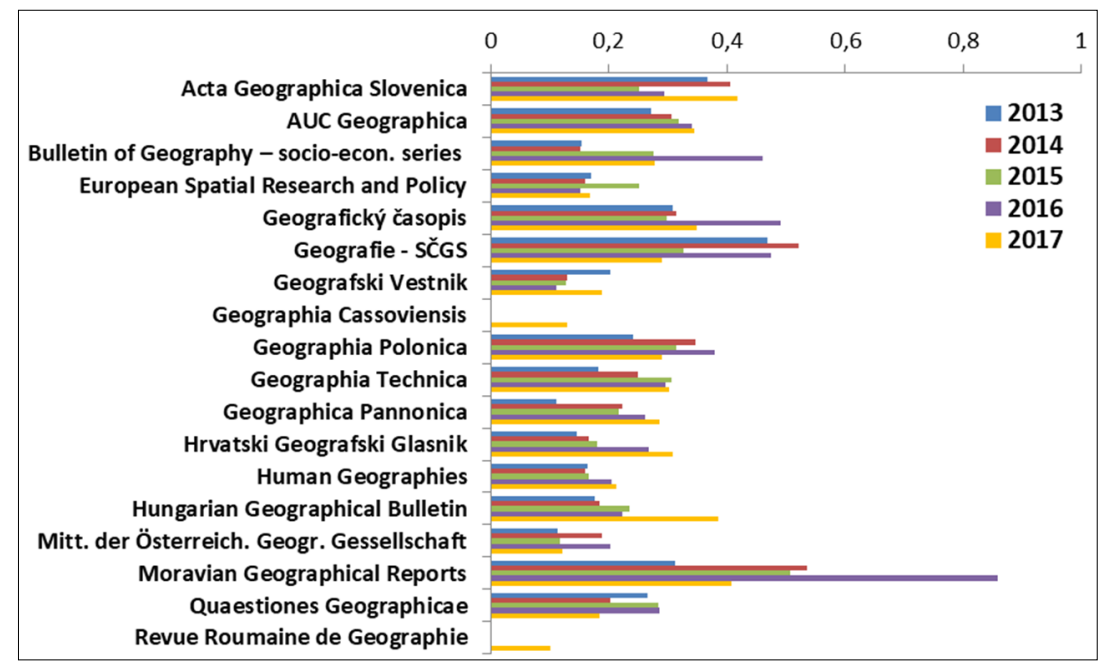

Obr. 5. Index SJR analyzovaných časopisov (2013 - 2018)

\section{ZÁVER}

V príspevku sme sledovali ciel' predstavit' sedem desat'ročí vo vývoji GČ a na základe stručnej analýzy publikovaných štúdií a článkov poukázat' na niektoré črty vývoja geografického myslenia na Slovensku. Na základe scientometrických porovnaní vychádzajúcich z citačnej analýzy časopisov na základe databáz WOS a Scopus sme sa pokúsili charakterizovat' postavenie GČ v medzinárodnom kontexte geografických periodík stredo-východoeurópskeho priestoru.

Do konca 20. storočia sa postupne geografické časopisy stali dominantnou akademickou vydavatel'skou činnost'ou v geografii. V tomto období, ked' sa uverejnenie článku vo vedeckom časopise stalo nevyhnutnou podmienkou publikačnej čin- 
nosti, komerčne orientované vydavatel'stvá začali dominovat' na trhu s vydavaním časopisov (Berg 2009). Tieto procesy boli zakotvené v širších procesoch v rámci akademického prostredia a viedli k vzostupu akademického kapitalizmu, homogenizácii predaja a distribúcie geografických časopisov (Paasi 2005) i vytváraniu formy citačného vedomia. Výsledkom je to, že komerčné vydavatel'stvá a producenti citačných databáz získali značnú kontrolu nad systémom vedeckého publikovania v geografii. Zároveň sa aktívne zúčastňujú (podiel'ajú) na meraní „hodnoty“ týchto časopisov pomocou výpočtov faktorov dosahu a poradia časopisov. Súčasnú situáciu možno charakterizovat' skutočnost'ou, že väčšina (najmä mladých) geografov je odradená od publikovania v čomkol'vek inom, než vo vysoko hodnotených časopisoch meraných impakt faktorom. Napriek šíreniu časopisov vydávaných vedeckými inštitúciami, univerzitami a vedeckými spoločnost'ami sa edičné prostredie geografických časopisov stáva menej rozmanitým a prísnejšie kontrolovaným štrukturálnymi obmedzeniami (Berg 2009, Jančák a Siwek 2014 a Śleszyński 2014). Je zrejmé, že časopisy s podobným spôsobom vydávania sú často znevýhodňované a ich zápas o úspešnost' je čoraz zložitejší.

Geografický časopis napriek nie jednoduchým podmienkam prispieval od 90. rokov k stimulovaniu výskumu a diskusie v rámci viacerých nových výskumných agend, ale aj pri renesancii niektorých subdisciplín a výskumných okruhov geografie. Nové príležitosti pre výskum a analýzu vychádzali z:

- technologickej inovácie v telekomunikáciách a doprave,

- masívneho využívania nových softvérov najmä v oblasti geografických informačných systémov,

- globálnej a regionálnej (najmä európskej) integrácie,

- zmien v kvalite životného prostredia,

- zmien krajinnej pokrývky na jednej strane $\mathrm{v}$ dôsledku intenzívneho využívania (napr. suburbanizácia), na druhej strane v dôsledku pustnutia,

- (ne)udržatel'nosti rozvoja výroby, dopravy, spotrebitel'ského správania,

- meniacej sa kvality života ovplyvnenej zmenami v spoločnosti (napr. chudoba, kriminalita a dostupnost' služieb),

- marginalizácie určitých skupín obyvatel'ov (a ich obáv z rastu chudoby) nárastom sociálnych a ekonomických nerovností, ako aj priestorovýchúzemných disparít,

- demografických zmien vyvolaných spoločensko-politickými a kultúrnymi zmenami s dosahom na zmenu demografického správania,

- nárastu cestovania, rekreácie a cestovného ruchu a zo zmien vo využívaní vol'ného času,

- pokračujúceho teoretického a metodologického vývoja.

Časopis za ostatných viac ako dvadsat'pät' rokov umožnil čitatel'om byt' svedkom mnohých zmien v strategických smeroch periodika, ako aj v najnovších výskumných trendoch a aktuálnych témach týkajúcich sa geografického výskumu po celom svete. Časopis bol vždy otvorený a ústretový voči autorom z celého sveta. Počet príspevkov zo Slovenska, Česka a d’alších krajín strednej Európy však stále výrazne prevyšoval počet článkov z ktorejkol'vek inej časti sveta. Príspevky publikované v časopise odrážali hlavné silné stránky a dôrazy geografie a boli dobre 
zastúpené univerzitami a výskumnými pracoviskami s renomovanými autormi, ale aj mladými vedeckými pracovníkmi.

Časopis sa stal prívetivejším pre výskumníkov, ktorí nie sú geografmi, ale majú spoločný záujem riešit' časovo-priestorové problémy človeka (spoločnosti) a jeho (jej) prostredia. Týmto spôsobom sa časopis stáva všeobecne známejším pre širšiu komunitu výskumníkov a to tiež pomáha geografii otvorit' sa iným perspektívam. Tento prístup umožňuje publikovat' práce sústredené na vybrané regióny a témy. Špeciálne problémy vel'mi často vyvolali teoretické diskusie a diskusie o kl'účových témach v geografii. Tento trend má šancu byt' ešte viac posilnený.

Mimoriadne bohaté súbory údajov umožňujú autorom zaoberat' sa aj starými problémami pomocou nových techník a metód. Domnievame sa, že v súčasnosti je vhodný čas na to, aby sa vedci viac zamýšl'ali aj nad teoretickými prínosmi týchto prác. Potešitel'né je, že v ostatných rokoch možno vidiet' aj nárast počtu príspevkov týkajúcich sa teoreticko-geografických problémov. V geografickej komunite, ako aj v príbuzných odboroch zaoberajúcich sa výskumom zmien v prostredí (krajine), stúpa záujem o to, ako môže výskum prispiet' k udržatel'nému smerovaniu rozvoja územia a vyššej kvalite života jeho obyvatel'ov.

Nazdávame sa, že napriek niektorým nepriaznivým aspektom vývoja v oblasti publikovania výsledkov vedecko-výskumnej činnosti, (časovo)priestorový rozmer a perspektívy spoločenských vied, prírodných vied a vied o človeku a jeho prostredí budú mat' v budúcnosti d’alšie možnosti a príležitosti na diskusiu na stránkach GČ. Predpokladáme, že časopis bude mat' v d'alších rokoch dostatočne priaznivú pozíciu, aby prinajmenšom v stredoeurópskom kontexte podporoval interdisciplinárny syntetizujúci výskum orientovaný na časovo-priestorové interakcie človeka (spoločnosti) a prírodného prostredia. Poslaním všetkých autorov publikujúcich v GČ v budúcnosti zostáva rozširovat' poznanie z časovo-priestorových (geografických) výskumov nielen medzi geografmi, ale aj medzi odborníkmi z príbuzných disciplín.

Príspevok bol vypracovaný v rámci riešenia projektu 1/0049/18, ktorý je finančne podporovaný grantovou agentúrou VEGA.

\section{LITERATÚRA}

BAJERSKI, A., SIWEK, T. (2012). Bibliometrická analýze české geografie v databázi SCOPUS. Geografie, 117, 52-71.

BARÁTH, J., SZÔLLÖS, J., ČERNÁK, P. (1995). Analýza stability územia volebnej podpory vybraných politických strán (na základe výsledkov volieb 1990, 1992 a 1994). Geografický časopis, 47, 247-259.

BAŠOVSKÝ, O. (1986). Funkcie miest a ich interpretácia z hl'adiska vývoja regionálnej štruktúry SSR. Geografický časopis, 38, 126-136.

BERG, D. B. (2009). Geographical Journals. In Kitchin, R., Thrift, N., eds. International encyclopedia of human geography Vol. 4, Amsterdam, Boston, Heidelberg, London, New York, Oxford, Paris, San Diego, San Francisco, Singapore, Sydney, Tokyo (Elsevier), pp. 394-401.

BEZÁK, A. (1975). Niekol'ko poznámok k matematickému modelovaniu v ekonomickej geografii. Geografický časopis, 27, 9-15.

BEZÁK, A. (1990). Funkčné mestské regióny v sídelnom systéme Slovenska. Geografický časopis, 42, 57-73.

BEZÁK, A. (1993). Súčasný stav a perspektívy Geografického ústavu SAV. Geografický časopis, 45, 359-381. 
BISSELL, D. (2019) Social \& cultural geography at 20 years: Looking back, thinking forward. Social \& Cultural Geography, 20, 1-3, DOI: 10.1080/14649365.2018.1554162.

BLAŽEK, J. (1986). Využití analýzy citačních ohlasů v geografii. Sborník Československé geografické společnosti, 91, 140-149.

BOSMAN, J. (2009). The changing position of society journals in geography. Tijdschrift voor Economische en Sociale Geografie, 100, 20-32. DOI: 10.1111/j.14679663.2009.00511.x.

De PATER, B. (2009), From a magazine for 'practical gentlemen' to an academic journal: one hundred years of TESG. Tijdschrift voor Economische en Sociale Geografie, 100, 5-19. DOI: https://doi.org/10.1111/j.1467-9663.2009.00502.x.

DOBBERSTEINOVÁ, J., HUDECOVÁ, S., STOŽICKÁ, Z. (2019). Sprievodca svetom vedeckého publikovania. Bratislava (Vydavatel'stvo otvorenej vedy, Centrum vedeckotechnických informácií SR).

DRDOŠ, J. (1978). Geografia a jej úlohy pri ochrane a tvorbe životného prostredia. Geografický časopis, 30, 218-226.

FABIAN, O. (2012). Elektronické informační zdroje. Praha (NAKLIV).

FERANEC, J., OTAHEL, J. (1999). Mapovanie krajinnej pokrývky metódou CORINE v mierke 1:50 000: návrh legendy pre krajiny programu Phare. Geografický časopis, 51, 19-44.

FYFE, A., McDOUGALL-WATERS, J., MOXHAM, N. (2015). Guest editorial: 350 yeras of scientific periodicals. Notes and Records, 69, 227-239. DOI: 10.1098/rsnr.2015.0036.

GRIFFITH, D. A., CHUN, Y., O'KELLY, M. E., BERRY, B. J. L., HAINING, R. P., KWAN, M-P. (2013). Geographical analysis: Its first 40 years. Geographical Analysis, $45,1-27$.

HANUŠIN, J., BETÁK, J., CEBECAUEROVÁ, M., GREŠKOVÁ, A., HUBA, M., IRA, V., LACIKA, J., LEHOTSKÝ, M., PODOLÁK, P. (2008). Protected areas in the context of selected aspects of sustainable development in the Tatra region. Geografický časopis, 60, 129-148.

HANZLÍK, J. (1967). Vývoj obyvatel'stva na Slovensku v období 1869-1961. Geografický časopis, 19, 3-30.

HOFIERKA, J., GALLAY, M. (2013). Publikačná činnost geografických pracovísk na slovenských vysokých školách v období rokov 2007-2013. Geographia Cassoviensis, 7(2), 22-30.

HUBA, M. (1982). Štrnást' krokov na ceste za krajinným plánom. Geografický časopis, 34, $145-160$.

HUBA, M., IRA, V. (1996). O koncepcii trvalej udržatel'nosti vo vzt'ahu k niektorým geografickým aspektom vývoja Slovenska. Geografický časopis, 48, 285-299.

IRA, V. (1994). Environmental perception and environmental awareness at the area with disturbed environment (upper Nitra region). Geografický časopis, 46, 173-188.

IRA, V. (2013). História a súčasný stav vedeckovýskumnej činnosti Geografického ústavu Slovenskej akadémie vied. In Ira, V., Michniak, D., Šuška, P., Šveda, M., eds. Reflexie časovo-priestorových výskumov $v$ geografii: zbornik abstraktov. Bratislava (Geografický ústav SAV), pp. 7-19.

IRA, V. (2017). Príspevok Geografického časopisu k starostlivosti o životné prostredie. Zivotné prostredie, 51(2), 93-96.

IRA, V. ANDRÁŠKO, I. (2007). Kvalita života z pohl'adu humánnej geografie. Geografický časopis, 59, 159-179.

IRA, V., DURIŠOVÁ, E., ŠUŠKA, P. (2016). Geografický časopis (Geographical Journal) in time and Central European space. In Lňenička, L., ed. Central Europe Area in View of Current Geography. Proceedings of 23rd Central European conference. Brno (Masaryk University), pp. 455-459.

IVANIČKA, K. (1965). Metodologický rozvoj a súčasné problémy ekonomickej geografie. Geografický časopis, 17, 134-152.

JAKÁL, J. (1978) Atlas Slovenskej socialistickej republiky už vychádza. Geografický časopis, 30, 173-188. 
JANČÁK, V., SIWEK, T. (2014). Výsledky českých geografů publikované v časopise Geografie v letech 2008 - 2013. In Siwek, T., Jančák, V., eds. 120 let České geografické společnosti. Praha (Česká geografická společnost), pp. 81-320.

JELEČEK, L., MARTÍNEK, J. (2007). Nástin dějin Ceské geografické společnosti. Klaudyán: internetový časopis pro historickou geografii a environmentální dějiny, 4(2), 4248.

JOHNSTON, R. J. (2003). The institutionalization of geography as an academic discipline. In Johnston, R. J., Williams, M., eds. A century of British geography. Oxford (Oxford University Press), pp. 45-97.

KATUŠČ́AK, D. (2005). Citovanie a zoznam bibliografických odkazov v práci In Meško, D., Katuščák, D., eds. A kademická príručka, 2. dopl. vyd. Martin (Osveta) pp. 215-238.

KIMLIČKA, Š. (2002) A ko citovat' a vytvárat' zoznamy bibliografických odkazov podl'a noriem ISO 690 pre ,klasické “ aj elektronické zdroje. Bratislava (Stimul).

KNOWLES, R. D. (2019). How the Journal of Transport Geography has evolved since 1993. Journal of Transport Geography, 81, 1-4. DOI: https://doi.org/10.1016/ j.jtrangeo.2019.102525.

KOLLÁR, D. (1992). Sociálna geografia a problematika výskumu priestorového správania človeka. Geografický časopis, 44, 149-161.

KOREC, P., RUSNÁK, J. (2018). Prístupy humánnej geografie - filozofia, teória a kontext. Bratislava (Univerzita Komenského v Bratislave).

KRCHO, J. (1968). Prírodná čast' geosféry ako kybernetický systém a jeho vyjadrenie v mape. Geografický časopis, 20, 115-130.

KRIŽAN, F., BILKOVÁ, K., KITA, P., KUNC, J., BARLIK, P. (2015). Nákupné centrá v Bratislave a atribúty ovplyvnuujúce preferencie spotrebitel'ov. Geografický časopis, 67, 341-357.

KUHN, T. S. (1997). Struktura vědeckých revolucí. Praha (Oikoymenh).

KVITKOVIČ, J. (1993). Vývoj geografického ústavu SAV v rokoch 1953 - 1990. Geografický časopis, 45, 317-326.

LEHOTSKÝ, M., GREŠKOVÁ, A. (2007). Fluvial geomorphological approach to river assessment - methodology and procedure. Geografický časopis, 59, 107-129.

LUKNIŠ, M. (1949). Život a dielo univ. prof. Dr. Jána Hromádku, Geographica Slovaca, 1, $1-6$.

LUKNIŠ, M. (1985). Regionálne členenie Slovenskej socialistickej republiky z hl'adiska jej racionálneho rozvoja. Geografický časopis, 37, 137-163.

MARIOT, P. (1971). Funkčné hodnotenie predpokladov cestovného ruchu ako podklad pre vytvorenie priestorového modelu cestovného ruchu. Geografický časopis, 23, 242-253.

MARTINKA, J. (1956). Historickogeografické črty Žitného ostrova. Geografický časopis, 8, 134-139.

MATLOVIČ, R. (2011). Prešovská geografická škola (polstoročie samostatnej katedry geografie). Folia geographica, 17, 5-25.

MATLOVIČ, R., MATLOVIČOVÁ, K. (2015). Geografické myslenie. Prešov (FHPV PU v Prešove).

MATLOVIČ, R., MATLOVIČOVÁ, K. (2020). First and second order discontinuities in world geographical thought and their primary reception in Slovak geography. Folia Geographica, 62, 52-76.

MAZÚR, E. (1963). K problematike geomorfologického mapovania všeobecne a so zvláštnym zretel'om na územie ČSSR. Geografický časopis, 15, 102-114.

MAZÚR, E. (1978). 25 rokov Geografického ústavu Slovenskej akadémie vied. Geografický časopis, 30, 200-217.

MAZÚR, E., DRDOŠ, J. URBÁNEK, J. (1983). Krajinné syntézy - ich východiská a smerovanie. Geografický časopis, 35, 3-19.

MAZÚR, E., LUKNIŠ, M. (1978). Regionálne geomorfologické členenie SSR. Geografický časopis, 30, 101-125.

MIČIAN, L. (1971). Nejednotnost' názorov na systém fyzickogeografických vied. Geografický časopis, 23, 156-159. 
MIČIAN, L. (1999). Geografia, fyzická geografia, krajinná ekológia, geoekológia: ich interpretácie a funkcie. Geografický časopis, 51, 331-345.

MIČIETOVÁ, E. (1999). Kvalita, funkcie a operačné možnosti databázy geografického informačného systému. Geografický časopis, 51, 297-312.

MICHÁLEK, A. (1995). Priestorová diferenciácia kriminality a vybraných trestných činov v SR (na úrovni okresov). Geografický časopis, 47, 93-108.

MICHÁLEK, A. (2000). Chudoba, jej koncepty a geografické dimenzie. Geografický časopis, 52, 231-242.

MICHNIAK, D. (2003). Dostupnost' okresných miest na Slovensku. Geografický časopis, 55, 21-39.

MINÁR, J. (1998). K niektorým problémom geomorfologického mapovania. Geografický časopis, 50, 247-259.

MINÁR, J. (2009). Geografické polia a priestorová organizácia krajiny (pokus o vyjasňovanie základných konceptov). Geografický časopis, 61, 179-198.

MLÁDEK, J. (1986). Vzt’ah urbanizácie a industrializácie v Slovenskej socialistickej republike. Geografický časopis, 38, 186-198.

MLÁDEK, J., KÁČEROVÁ, M. (2008). Analysis of population ageing in Slovakia: Time and regional dimensions, Geografický časopis, 60, 179-197.

OČOVSKÝ, Š. (1977). Odraz výskumov vnútorného obchodu v geografickej literatúre. Geografický časopis, 29, 52-64.

ONDOS, S., KOREC, P. (2008) The rediscovered city: a case study of post-socialist Bratislava. Geografický časopis, 60, 199-213.

ONDRIŠ́OVA, M. (2011). Bibliometria. Bratislava (STIMUL).

OŤAHEL, J., FERANEC, J. (1997). Mapovanie využitia krajiny a krajinnej pokrývky na Slovensku. Geografický časopis, 49, 35-45.

PAASI, A. (2005). Globalisation, academic capitalism and the uneven geographies of international journal publishing spaces. Environment and Planning A, 37, 769-789. DOI: $10.1068 / \mathrm{a} 3769$.

PACIONE, M. (2014). Scottish geography: A historiography. Glasgow (The Royal Scottish Geographical Society).

PAULOV, J. (1966). Niektoré problémy a aspekty exaktizačného procesu v geografii. Geografický časopis, 17, 252-268.

PAULOV, J. (1986). Spory o pozitivizmus v súčasnej západnej geografii. Geografický časopis, 38, 260-273.

PAULOV, J. (2012). Základné paradigmy v rozvoji geografie ako vedy: pokus o stručnú identifikáciu. Geografický časopis, 64, 111-120.

PODOLÁK, P. (1993). Príspevok k regionálnej diferenciácii demografických štruktúr. Geografickýčasopis, 45, 19-27.

POLACIK, S (1977). Delimitácia mnohoznakových homogénnych regiónov pomocou numerickej taxonómie. Geografický časopis, 29, 67-84.

PRAVDA, J. (1985). Rozvoj teórií v kartografii. Geografický časopis, 29, 346-358.

PRICE, M. (2010) The centennial forum: An introduction, Annals of the Association of American Geographers, 100(5), 1047-1048. DOI: 10.1080/00045608.2010.523333.

RADVÁNI, P. (1983). Mesto a jeho obraz. Geografický časopis, 35, 395-408.

ROCHOVSKÁ, A., BLAŽEK, M., SOKOL, M. (2007). Ako zlepšit' kvalitu geografie: o dôležitosti kvalitatívneho výskumu v humánnej geografii. Geografický časopis, 59, 323-358.

ROUSSEA, U. (2008). Publication and citation analysis as a tool for information retrieval. In Goh, D., Foo, S., eds. Social information retrieval systems: Emerging technologies and applications for searching the web effectively. IGI Global, pp. 252-254. [Online]. Dostupné na: http://www.igi-global.com/viewtitlesample.aspx?id=29168 [cit. 2015-0831].

SMITH, C. H. (2013). On the system of knowledge: A classification of studies within the field of geography. DLPS Faculty Publications. Paper 61, [Online]. Dostupné na: http:// digitalcommons.wku.edu/dlps fac pub/61 [cit. 2015-08-31]. 
STANKOVIANSKY, M. (1992). Hodnotenie stavu prírodných a prírodno-antropogénnych morfolitosystémov (na príklade vybranej časti Bratislavy). Geografický časopis, 44, 174-187.

ŚLESZYŃSKI, P. (2014). 50 years of Geographia Polonica in the light of citations. Geographia Polonica, 87(1), 143-155. DOI: https://doi.org/10.7163/GPol.2014.9.

ŠVEDA, M. (2011). Suburbanizácia v zázemí Bratislavy z hl’adiska analýzy zmien krajinnej pokrývky. Geografický časopis, 63, 155-173.

ŠÚRI, M. (1991). Vplyv reliéfu na priestorovú diferenciáciu dát družoce LANDSAT 5. Geografický ćasopis, 43, 27-43.

URBÁNEK (1992). Krajina - vec alebo proces? Geografický časopis, 44, 217-236.

URBÁNEK (1997). Geomorfologická mapa: niektoré problémy geomorfologického mapovania na Slovensku. 49, 175-186.

URBÁNEK, J., MAZÚR, E., DRDOŠ, J. (1980). The search for the new way of the landscape study. Geografický časopis, 32, 108-118.

WARD, K., COOKE, T. J., SHEARMUR, R., WYLY, E., HANSON, S., LAKE, R., ADAMS, J. S. (2020). 40 years of the journal Urban Geography, Urban Geography, 355 -367. DOI: $10.1080 / 02723638.2020 .1723368$.

WITLOX, F., SCHWANEN, T. (2019). Looking back, to move forward: Celebrating 25 years Journal of Transport Geography, 81, 1-3. DOI: https://doi.org/10.1016/ j.jtrangeo.2019.102591.

ŽUDEL, J. (1974). Vplyv ekonomickej činnosti Fuggerovcov na životné prostredie v oblasti Červenokamenského panstva v rokoch 1535-1583. Geograficky časopis, 26, 163-174.

ŽUDEL, J. (1993). Dejiny Zemepisného ústavu Slovenskej akadémie vied a umení 19431953. Geografický časopis, 45, 309-316.

Internetové zdroje:

http://geograficky-casopis.sav.sk/

https://www.scimagojr.com/

https://www.scopus.com/search/form.uri?display=basic

http://apps.webofknowledge.com/WOS GeneralSearch input.do?

$\underline{\mathrm{SID}=\text { E6ipbZOQHkxKuR2VLCo\&product }=\text { WOS\&search mode }=\text { GeneralSearch }}$

Vladimír Ira, Eva Ľ u rišová, Pavel $\check{S} u s ̌ k a$

\section{GEOGRAFICKÝ ČASOPIS / GEOGRAPHICAL JOURNAL: 70 YEARS SHAPING GEOGRAPHICAL THOUGHT IN SLOVAKIA}

Geography as a science enjoys long history but its formal institutionalization as an academic discipline with established identity is a phenomenon of the end of the 19th century and the beginning of the 20th century. Opening of university departments and institutes of geography, introduction of study programmes and geographical research was part of a wider spectre of processes accompanied by publishing of geographical periodicals since the 19th century.

However, favourable conditions for a systemised development of publishing of the scientific results in the Slovak language came only after the WWI and after the foundation of the Czechoslovak Republic in 1918. Before 1949, there did not exist any journal dedicated to the geographical research in Slovakia. Geografický časopis filled this gap. Seventy years after publishing of this periodical for the first time inspired authors of this article to ponder over the metamorphoses of this oldest geographical journal and to analyze its legacy and significance. The journal appeared for the first time in 1949 as Geographica Slovaca, while the following three years $(1950$ - 1952) it bore the title Zemepisny sbornik SAVU which was changed to Geografický časopis in 1953.

Geografický časopis (print ISSN 0016-7193, on line ISSN 2453-8787) is a peer reviewed scientific journal which publishes original scientific studies bringing the most re- 
cent knowledge of all fields of geography and important papers of related disciplines such as landscape ecology, hydrology, climatology, pedology, environmental science, cartography, geo-information science, sociology and economy. Studies devoted to the geographical research in Slovakia and countries in the Central European space, as well as those involved with the theoretical and methodological questions of geographical research are given preference. Nowadays, the journal appears four times a year in Slovak or Czech with English summaries or in English accompanied by Slovak summaries.

Geografický časopis (further on GČ) has been indexed in the SCOPUS citation database in the years 1979-1995 and from 2007 until now while 253 issues of the journal published in 1949-2018 contain 1,366 articles, studies and scientific reports written by a total of 1,868 authors. The majority $(1,110)$ of articles were published in Slovak and Czech, 227 in English, 24 in German, 4 in Russian and 1 in French. The scope of all articles represents now 20,585 pages. The most distinct group of contributors to Geografický časopis were Slovak and Czech authors from scientific-research institutions and universities. Foreign authors who published in the journal were from Poland (34 articles), Germany (14), Hungary (13), former Soviet Union and Russia (13), Romania (6), Austria (5), England (4), and France (3). Foreign authors include renowned scientists from Austria, Belgium, Canada, Czechia (including former Czechoslovakia) France, Germany, Italy, Poland, Romania, Russia (or Soviet Union), Netherlands, Slovenia, Switzerland, United Kingdom, and USA.

The time line of our analysis is based on the turning periods characterized by great political and socio-economic changes (Tab. 3). The first period consisted of three decades starting by the foundation of the journal until 1968; the second started in 1969, when regulation and even censorship became ever more notable. The third period (1990-2018) was influenced by the sensible political and social changes in Czecho-Slovakia and in Central and Eastern Europe on the one side and global change and changes in the field of information and communication technologies on the other.

The brief overview presented in Tab. 3 demonstrates that physical-geographical subdisciplines such as geomorphology (morphogeography) pedogeography, climatology (climageography) and meteorology, hydrogeography, and historical geography dominated in the first two decades. Papers involved with geomorphology, pedogeography, climatology and meteorology, hydrogeography and biogeography were again the ones most represented in the period after 1968 until 1989. Due to the newly formed geoecological school in Slovakia, papers dealing with geoecology and complex physical geography appeared. The interest of the whole world in environmental issues has been also reflected in publications of authors focused on the environmental geography. Activities associated with production of atlases (first of all Atlas of the SSR) resulted not only in publications concentrated on questions of regional geography and regionalization but also on the themes of cartography. The period after 1989 is characteristic for a distinct amplification of the themes. The profile of Geografický časopis typical for the structure of published articles has, thanks to the new geographically relevant global and regional phenomena but also due to the progress of information technologies and research methods as well as a deeper reflection on the changes in geographical thought in the world, considerably changed. Apart from the continuous interest to publish papers concerned with geomorphology (especially the fluvial geomorphology), hydrogeography, and geoecology, authors were also involved with other traditional fields such as population geography and demogeography (questions of ethnicity and religiosity) and urban geography (particularly transformation of urban structures and suburbanization). A number of topical issues brought about by the post-socialist transformation became the research theme of human and regional geography. Attention has been given to regional differences and the new hierarchic organization of the state, unemployment and its regional differences, accessibility, mobility and migration, quality of life and its measures, poverty, crime and its spatial aspects. Political geography was represented mostly by studies dealing with the electoral geography. Environmental geography focused on environmental perception and issues of sustainability. Many of them though, studied the issue of 
the land-use/land-cover change, themes of theoretical geography, cartography and the GIS, remote sensing and geoinformatics.

The development of the geographical thought as presented in articles of Geografický časopis can be also seen in the conceptual frame of research concentrated on discontinuities in scientific thought and their reception in geography as formulated by Matlovič and Matlovičová (2020). The beginnings of the modern geographical thought in Slovakia are connected with the French school of regional geography. Its effects are obvious in the very first articles of the Journal. Since the beginning of the 1950s, the works published in this journal started to abandon this paradigm due to transition to the paradigm of dialectic and historic materialism. Tendency to complex approaches appeared in publications in the 1960s. In spite of the fact that this paradigm was binding until the period of social and political change in 1989 and 1990, several authors successfully reflected almost all discontinuities of the given period. As Matlovič and Matlovičová (2020) report, after admitting the qualitative discontinuity, geography in Slovakia also responded comparatively early to the systemic and comprehensive discontinuity. Systemic approach was first applied in the physical-geographical research. Geosystem approach was applied to the creation of the conception of landscape synthesis (Mazúr et al. 1983). Behavioural discontinuity ripened into the first responses in the Slovak geographical community already in the 1970s. The first studies were involved with the perception and evaluation of the environmental quality. However, Geografický časopis only presented this current of geographical thought in the 1980s-1990s. The post positivist discontinuity initiated the first reflection of J. Paulov (1986) published in the Journal. The structural discontinuity and cultural discontinuity or conceptions of the new cultural geography was not talked about in the Journal. The postmodern discontinuity was only reflected on into summarizing studies. Generally, the potential of the post-modern post-structuralist geography in Slovakia (including the Journal) was scarcely exploited (Matlovič and Matlovičová 2020).

As far as the evaluation of articles published in Geografický časopis by means of citations by the Web of Science and Scopus citation databases is concerned, the result was: 1,226 entries in the WOS, citing articles in the GC and 1,336 entries in the Scopus database (as of 25 March 2019). The statistical overview of citations is presented by individual years (Tab. 4), decades (Fig. 1) and three analyzed periods (Tab. 5) of the existence of the Journal. The most quoted studies in the 1970s and 1980s were the ones treating the regional division of Slovakia. After 1990 the most cited studies were involved with the theme of functional urban regions, land cover changes and the geographical aspects of the quality of life. Comparison of Geografický časopis to 18 selected Central and Eastern European periodicals (Tab. 6) highlights the quantitative indicators used in the SCOPUS database. Selection of 18 Central and Eastern European journals was ruled by the idea that they were indexed in this database.

The analysis of Fig. 2, 3, 4 and 5 (processed SCOPUS data and those of the Scimago Journal Rank Portal) revealed that there are no important differences between the journals. The best journal in the relevant study period and in terms of quantitative indicators seems to be the journal Moravian Geographical Reports which entered the category of journals classified in the first quartile in 2016. Journals Acta Geographica Slovenica, AUC Geographica, Geografický časopis, Geografie - Sborník ČGS, Geographia Polonica were also in the first half of the set of journals in the category Geography, Planning and Development (2nd quartile) and the Hungarian Geographical Buletin joined them in 2017. Geografický časopis has maintained a comparatively stable level in recent years.

Ambition of this article was to outline, albeit briefly, the development of Geografický časopis. Like in other countries, our journal became in the mid-20th century an important part of the publishing environment in geography. By the end of the 20th century, geographical journals progressively became a dominating academic publishing activity. In the same period, commercially oriented publishers dominated in the journal publishing market (Berg 2009). These processes were anchored in a wider series of actions and steps in the academic environment and led to the rise of the academic capitalism, homogenization of 
sale and distribution of geographical journals (Paasi 2005), and creation of the citation awareness. The result is that the commercial publishers acquired a considerable control over the system of scientific publishing in geography. Despite of not very favourable situation (journal is published by an academic institution), Geografický časopis contributed to the stimulation of research and discussion in the frame of several new research agendas in Slovakia since the 1990s.

During the last more than 25 years, the Journal offered its readers the opportunity to witness many changes in its strategic orientation and the most recent research trends and topical themes of the geographical research pursued the world around. Authors making use of abundant data sets also treat the old problems applying new techniques and methods. It is gratifying that the number of contributions concerning theoretical-geographical problems has increased in recent years. In spite of some adverse aspects of the development in the field of publishing, the spatio-temporal dimension of the research and perspectives of sciences, social sciences and humanities will enjoy additional options and opportunities for the discussion on the pages of Geografický časopis. The journal will certainly benefit from a sufficiently favourable position to be able to support research, at least in the Central European space, focused on humans in the changing environment. The mission of all authors who publish in Geografický časopis will remain the same, that is, propagation of the knowledge acquired in the time-space research not only among geographers but also among experts in the related sciences. 